\title{
The Topography of Corporal Relics in Twelver Shicism
}

\author{
Some Anthropological Reflections on the Places of Ziyāra
}

\author{
Sepideh Parsapajouh | oRCID 0000-0002-3202-386X \\ Research fellow, French National Centre for Scientific Research (CNRS-CéSor), Paris, \\ France \\ sepideh.parsapajouh@ehess.fr
}

\begin{abstract}
Because of the plurality of the venerated figures, the holy places of Twelver Shi ism are numerous. This paper focuses on places of devotion that are supposed to contain bodily relics and presents them in a schematic framework to discuss the importance of some of these places, and some aspects of their transformations over time. I first identify the sacred figures of Shi'ism and the place or the places (multi-locality of tombs) attributed to each of them. I then move on to a discussion of two things that can seem paradoxical, i.e. the immateriality of the sacred figure, and his/her omnipresence beyond places. My findings are based on field observations and interviews, and on documentary and published sources.
\end{abstract}

\section{Keywords}

bodily relics - multi-location of Imam's grave - Twelver Shi'a - Imamī devotions - Imam 'Alī's Shrine - Imam Husayn's head - saintly figures of Shi'ism - holy places of shi'ism - substitute

Introduction

In Imamī or Twelver Shi'a Islam, besides the great pilgrimage of Hajj, which is common to all Muslims, there are other forms of pilgrimage which, for some believers, are as important as the Hajj, or even more so. These "pilgrimages" are based on the sacredness of certain female and male figures in Shi'a history. This form of pilgrimage, which we will call the "pious visit" in this paper, has an equivalent in the Arabic term ziyāra, but is not, however, specific to Shica Islam. Innumerable works have been devoted to the worship of saints and pious visits in predominantly Sunni Sufi Islam. ${ }^{1}$ They point to a number of beliefs and practices that are common to what can be observed in Shicism. However, judging from compilations of Imamì hadiths - attributed to the Shici Imams dating back to the tenth century CE, it can be argued that Shi'ism is probably the oldest branch of Islam to have affirmed the legitimacy of this set of beliefs and practices.

In the pious visit, it is the idea of "encounter" that is important, rather than the idea of travel, movement and peregrination that emphasizes on a "journey". ${ }^{2}$ So the objective of the pious visit is the "encounter" with and communion with the divine man or woman, generally through his or her bodily remains. ${ }^{3}$ Thus, the pious visit is a moment of conjunction between the human and the divine, and takes place at the crossroads of three essential elements: a certain spiritual state, a set of ritual practices, and a material support, the latter often the place associated with the bodily remains or relics of the 
holy figure (always buried and never exposed externally). In this article I shall especially discuss this last point. ${ }^{4}$

So, a whole worship/cult of bodily relics exists within Twelver Shi'ism, which almost constitutes the Shi'ite 'act of faith'. It is a major phenomenon around which the sacred geography of Shi'ism is structured and organized, both canonical, even if discussed by theologians, and popular.

Considering the plurality and multiplication of the venerated figures in Twelver Shi'ism, the holy places are innumerable. I will focus on the places of devotion that are supposed to contain the bones and bodily remains (corporal relics). I shall try to present them in a schematic framework and to discuss some liturgical and emotional factors that explain the importance of some of these places, as well as some aspects of their transformations and changes over time. To explain where and why the holy figures are venerated, ${ }^{5}$ I shall first reveal, in what follows, the identity of the sacred figures of Twelver Shi'ism and the various places assigned to them. Next, I will discuss the multiplicity of tombs of the same figure. I will end with a passage on the holy places that do not contain relics and the possible differences between these two categories of places and their perception/understanding from the believer's point of view.

My findings are based on field observations and interviews (conducted between 2014-2018, in the case of Iran and Iraq, with Persian-speaking people), and on documentary and published sources. Their Sacredness?

The question of bodily relics in Shi ism is associated with the practice of pious visitation, or pilgrimage. This practice in Shicism, as in all religions, contains two aspects: an external aspect, which is objectively visible in places, and a hidden, internalized aspect made of the profound meanings that pilgrims and believers attribute to this visit, in other words, the value of this visit lays in the pilgrim's mind. If places and relics are important, it is through these values that simple believers and Shici theologians have attributed to them and that they call the "secrets" of the pious visit. In order to understand the importance of these places, it is worth starting with these questions: Who are the saints of Shicism and what meaning do believers attribute to their existence?

The most important category of sacred personalities, the saints par excellence, consists of a set of fourteen "Impeccables" ( $m a$ șüm ), considered free from all sin, who lived between the seventh and tenth centuries CE, namely the Prophet, his daughter Fātima, his cousin and Fāțima's husband Imam 'Alī, and eleven Imams descended from them.

These sacred people are referred to as the Ahl al-Bayt, the people of the House of the Prophet, or the Prophetic Holy Family. This idea is based first of all on the interpretation of the Quranic verse of the Tațīir (purification) (al-Ahazāb, 33:33): "Allah wants only to rid you of all defilement, O people of the House [of the Prophet], and to purify you completely".

But it is also based on many of the Prophet's hadiths, including that of "two weighty things" (al-thaqalayn): "I leave you two precious objects, the Book of God (the Quran) and my family. They will never be separated until the Day of Judgement ..."6 These sacred words are repeated by the Shi'a to accompany and justify their devotional practices towards these figures.

'Alī and his eleven descendants, the Twelve Imams of the Shi'a (whom I present below), are considered the successors and heirs of the Prophet, Muhammad who is 
himself considered to be the heir of all the previous prophets of the holy history of monotheism. As Mohammad Ali Amir-Moezzi insists, the term "Imam" in Shicism literally means a "divine guide" leading to salvation; it is inseparable from the term wali, "friend" or "ally of God" (wali Alläh). ${ }^{7}$ The Imam is a divine or theophanic man, the place of manifestation of divine secrets, also referred to for this reason in canonical sources as "the proof of God (hujjat Allāh)" or, in canonical traditions and recurring expressions of believers, as "the face of God (wajh Alläh)", and extensively analyzed by specialists such as Henry Corbin (1993) and Mohammad Ali Amir-Moezzi (2007, 2018).

For the Shi'a, the Imam is the place of manifestation of divine secrets. It is only

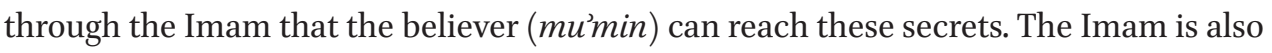
the guide, the one who leads to salvation. Believers call him the "ship of deliverance" (safinat al-najāt), according to a hadith attributed to the Prophet who said: "The people of my Family are like Noah's Ark, whoever embarks on it will be saved, whoever turns away from it will be drowned."

One of the essential notions that help us understand the importance of relics of sacred figures, the devotional practices of believers at holy places, and therefore also the meaning of the pious visit, lies in the notion of the waläya. It is a composite notion that signifies the alliance and friendship (or love) between God and the Imam, the nature and function of the Imam, his temporal and spiritual authority derived from the Prophet, and the love and obedience of the believer/devotee for and to him. The walāya is what connects the Imam to God, and the believer to the Imam. It is, in fact, through the alliance with Imams that the believer/devotee enters into an alliance with God. ${ }^{9}$

This notion has countless esoteric meanings among theologians and philosophers, but is translated concretely among believers, by the boundless love towards Imams, which is demonstrated by the pious visits to their tombs. The Shici community is thus formed, one might say, of all those who love Imams and whom Imams love.

A pilgrim told me the following about this love:

"Love for the Ahlal-Bayt is the beginning and the end of all things. It is the shortest and surest way to God. And it is very simple, you can have it with little effort. The rest of religion may be complicated; one can never be sure if it is respected properly! But love and friendship are unconditional," and she reminded me about a hadith of the Prophet engraved on the outer border of Imam 'Ali's shrine in Najaf: "If all men would gather around the love of 'Alī, God would never have created hell."10

The second fundamental point is the belief in the eternal existence of Imams.

In Shi'a belief, Imams are not simple human beings, as they are not limited to their historical existences. They are divine men, "beings" who existed before the creation of all "beings", who exist and will always exist independently from their lives on earth. They were created from a luminous substance emanating directly from the Divine Being before the creation of the world; this divine light constituted the beings of the Imams long before they manifested themselves in their human bodies. ${ }^{11}$

It is for this reason that in the mind of the believer they are always present and alive: they watch over the believers, hear them, speak to them and may also enter into different kinds of communication and interaction with them, according to their spiritual capacity. The believer addresses the Imam during her or his pious visit (ziyāra), speaks to him and makes requests to him: both for his intercession to God at the time of the Last Judgment, and for his intervention in the resolution of problems of this lower world. 
On an apparent, external, historical, and earthly level, Imams have died as martyrs and their graves are venerated, but on a metaphysical level, the Imam is a divine, timeless, eternal living being. He is never considered dead.

Nevertheless, in Shi'ism, as in many other religions, the believer needs concrete things as supports to practice his faith: these are particular places, objects and times, associated with the Imams, which materialize the sacredness of the Imams and which are at the center of pious visits to their tombs.

As mentioned in the introduction, the people revered and visited by the Twelver Shi'a are not limited to the fourteen impeccable people, including the Twelve Imams, but also include other people who have received sacredness through their kinship or alliance with the Imams, and their tombs have become objects of pious visitation or, in other words, a form of chain transmission of "sanctity". To understand this diversity, I propose the following typology.

\subsection{The Sacredness par excellence: The Impeccable Imams}

The first and most important category is that of the fourteen impeccable ones. They are the Shi'i saints par excellence and they occupy a unique position in beliefs and practices. Below are their names, some of their titles, virtues, and the location of their graves.

- The Prophet Muhammad (53 b.h./570-11/632), named Ahmad, i.e. "the most praised". He is the beginning and the source of the whole sacred chain that follows. His tomb is in Medina, within the current Mosque of the Prophet (Masjid an-Nabī). It is a highly sacred place for all Muslims who visit it, despite the severe constraints put in place by the Wahhabis (e.g. one cannot stop there).

- Fāțima, his daughter (c. 10 b.h. /612-11/632), ${ }^{12}$ known as Zahrā, i.e. "the luminous one". She is highly revered, and considered as the mother of all the Imams, and all believers (Umm al-Mu'minin). The highest woman in the worlds named the Mistress of the Women of the Worlds (sayyidat al-nisä al-'álamin). The story of her tragic death in her youth, shortly after her father's death, and the fact that neither the date of her death nor the place of her burial are known, have created a whole series of ritual practices around her memory, which believers carry out in different places. It is certain that she is buried in Medina. There are three hypotheses about the location of her grave, all deduced from historical testimonies and hadiths. They are: 1 . in her own house, located today close to the tomb of the Prophet (named hujrat al-sharif: noble room). This location is commonly accepted by Shici scholars like Shaykh Ṣadūq (3o6/917-381/991), Shaykh Mufìd (336/984-413/1022), Shaykh Ṭūsī (385/99546o/1067), Ibn Ṭāwūs (587/1192-663/1265), and follows the Imamī hadith; 2. within the Baqi' cemetery, next to the tomb of the four Imams (second: Hasan; fourth: Sajjād; fifth: Bāqir and sixth: Ṣādiq), and 3. within the Baqī cemetery in the small room where she used to mourn her father after his death, a place called Bayt al-Ahazann (The House of Sorrows), destroyed with other holy places in this cemetery in 1925 .

- 'Alī (23 b.h./599-40/661), the first Imam. His name means "the highest" (it is also one of the names of God). He is the Imam par excellence as the immediate successor of the Prophet, the father of all Imams, and the only one to bear the titles of Amir al-Mu'minin: "the Prince of the Believers", and Sayyid al-Wasiyin: "the Lord of the Legatees". The tomb of Imam 'Alī, today in Najaf, but also in Mazār-e Sharîf in Afghanistan (according to another account, see below), both venerated, has been hidden for decades.

- The first son of 'Alī and Fāṭima, al-Ḥasan (3/625-51/670), the second Imam, known as Karim $\bar{a} l-T a \bar{h} \bar{a},{ }^{13}$ i.e. the most generous of the Holy Family. He is also known for his beauty of soul. He is buried in Baqī' Cemetery in Medina. His tomb was destroyed in 1925 by the Wahhabi State, and Shi'a muslims are not allowed to enter the cemetery to visit him on their hajj pilgrimage. 
- The second son of 'Alī and Fāṭima, al-Ḥusayn (4/626-61/68o), the third Imam, commonly known as Sayyid al-Shuhadä, i.e. "the Lord of Martyrs". He was killed with seventy-two (probably a symbolic number) companions, including family members and children, by the army of Yazid, the Umayyad Caliph in 61/68o in Karbala. His murder represents the worst crime in history for the Shica, and is considered as the greatest evil suffered by the best of men. He is buried in his place of martyrdom, Karbala, with his family and companions. Hence the formation of this town over time, and its importance as a place of pilgrimage. ${ }^{14}$ His body is buried in this location, but various stories circulate about the whereabouts of his head (see below).

Al-Hasan and al-Husayn are both called "Sons of God's Envoy", the Prophet (Ibn Rasūl Allāh). They are his beloved grandsons and his only male descendants. Together they are surnamed "Lords of the Young Men of Paradise" (Sayyidā shabāb Ahl al-janna). ${ }^{15}$

These five people, who lived together during the mission of the Prophet, occupy a prominent place in Shi'a belief. According to a canonical hadith (hadith al-Kis $\left.\vec{a}^{\prime}\right),{ }^{16}$ the Prophet Muhammad gathered his four close relatives under a mantle before pronouncing the purification verse (Q 33:33) ${ }^{17}$ They are called the "People of the Mantle (ahl $\left.a l-k i s \bar{a}^{3}\right)$, often invoked together, as if they were one body. (The symbol of the hand of Fātima - well known in the Maghreb - represents these five bodies in Twelver Shica Islam).

- 'Alī son of Ḥusayn (38/659-95/713), the fourth Imam, called Zayn al-Ābidīn, i.e. "the Adornment of the Worshippers" or Sayyid al-Sājidinn, i.e. "the Lord of those who Prostrate Themselves before God". He is well-known for his knowledge and mystical states. He is the one who bore the pain of the tragedy of Karbala, which he witnessed and survived. He is also buried in Baqī Cemetery in Medina, next to the grave of his uncle, Hasan b. 'Alī.

- Muhammad, son of 'Alī (57/677-114/733), the fifth Imam, known as al-Bāqir, i.e. "the splitter-open of knowledge". His tomb is also in Baqī', next to his father.

- Ja'far son of Muhammad (83/702-148/765), the sixth Imam, called al-Ṣādiq, i.e. the Truthful one, with a with a very deep degree of knowledge. In fact, most of the Imami hadiths that define Shi'a doctrines are from these two Imams. He is buried next to his father. The graves of these four Imams were brought together in the same mausoleum in Baqi` before it was destroyed in 1925 .

- Mūsā son of Ja'far (128/745-183/799), the seventh Imam, named al-Kāẓim, i.e. who controls his anger. His life is marked by his imprisonment under the Abbasid caliphs. He is also called Bāb al-Hawāi $i$, meaning "the door to the accomplishment of wishes".18 He is buried in a place called Kāzimayn (or Kāẓimiyya), near Baghdad, which is regularly visited by Shi'i devotees.

- 'Alī son of Mūsā (148/766-203/818), eighth Imam, named al-Riżā, i.e. "the one agreedupon". He is celebrated for his mystical states. His life is marked by death in exile (at the court of the Abbasid caliph al-Ma'mun in Khorāsān, in north-eastern areas of present-day Iran, near present-day Turkmenistan and western Afghanistan), caused by a machination of the Caliph al-Ma'mūn (170/786-218/833). He is also called Gharīb al-Ghurabā, which means "the stranger among strangers". Iranians call him Sultān-e Khorāsān (the King of Khorāsān) and also Sulțān-e Jahān (the King of the World). He is the only one of the fourteen impeccable ones to be buried and visited in Iran, in the city of Mashhad, in Khorāsān.

- Muhammad son of 'Alī (195/811-220/835), the ninth Imam, called al-Jawād, i.e. "who gives and shares" (referring of course to the esoteric and mystical meaning of the term). His grave is next to his grandfather's in Kāzimayn. Both are placed in the same shrine, hence the plural name "Kāẓimayn".

- 'Alī son of Muhammad (214/828-254/868), the tenth Imam, named al-Hādī, i.e. "the one who guides", or al-Naqī, i.e. "the pure one". This Imam is buried in the military 
camp where he and his son were imprisoned in Sāmarrā, the Abbasid capital city with the same name in present-day Iraq. The shrine where his grave is located is named Haram 'Askarīyan.

- Hasan son of 'Alī (232/846-26o/874), the eleventh Imam, called al-'Askarī. His surname comes from the name of the military camp where he was under house arrest for most of his life. His grave is therefore, as we have just mentioned, next to that of his father, in the sanctuary of Sāmarrā; hence the plural name 'Askarīyan. ${ }^{19}$

- Muhammad son of Hasan (born c. c. 255/869), the twelfth Imam, named al-Mahdī, i.e. "the well guided". He is also called al-Qā’im, meaning "the resurrector or redeemer"; al-Ghā’ib, "the occult"; Șāḥib al-Zamān, "the Master of time"; al-Munjī, "the savior"; al-Muntaẓar, "the expected"; and Baqīyat Allāh al-A`ẓam, "the supreme remainder of God". He is believed to have been born and have lived in secret until the death of his father $(260 / 874)$. It is believed that he spent seventy years in Minor Occultation and have entered in Major Occultation in $329 / 941 .{ }^{20} \mathrm{He}$ is considered to be not dead, but alive, then invisible. He is expected to return at the end of times to avenge all the oppressed, and to bring justice to a world filled with injustice. ${ }^{21}$ His expectation conditions a series of pious acts among Shi'a who greet him daily and pray to speed up his coming. His status is different from others for the practices of intercession, because he is the Imam of the present time: he is everywhere and at all times and is visited in particular places connected to his earthly apparitions. Several places are attributed to him, where he would have appeared temporarily to certain people. These places are all considered to be very sacred, and venerated by believers, because they bear traces that this holy Imam would have left by his short presence and passage (see infra).

So, all these figures, with the exception of the twelfth Imam, are, according to Shi'i history, martyrs who have suffered the greatest persecutions and injustices. The graves of some of them, as we just mentioned, have been and still are, unknown or inaccessible, because of the historical minority status of Shi ism versus Sunni power and domination. However, the Shi'a people quietly consider their visits obligatory; this is reflected in the liturgical texts of the pious visitation, attributed to the Imams themselves, and very often recited by the faithful, but also in ancient collections of hadiths of the Imams, ${ }^{22}$ such as the Kāmil al-Zīyārāt of Ibn Qūlūyeh Qummī, (tenth century CE). The accessible tombs and mausoleums in Iran and Iraq are therefore the subject of extremely important practices of worship.

\subsection{The Sacredness through Bloodline:The Descendants of Imams (zurriya)}

The second category of venerated persons are some of the children and grandchildren of these Twelve Imams. They are called Imam-zādeh in Persian, zurriya in Arabic. This category consists of many minor saints, both male and female, who are related to the line of the "Fourteen Impeccables" (mașūm) by the filiation link. I insist here on the importance of the link through blood as transmitters of holiness among the Shi'a.

These minor saints are very numerous, particularly in Iran, where there are officially 10,615 Imām-zādehs, ${ }^{23}$ buried in 8,051 shrines of varying sizes. As an example, in Tehran and its surroundings, 337 mausoleums are piously visited. The city of Qom counts nearly 450 saints buried in 411 shrines, the most important of which is that of a lady of virginal purity, the sister of the eighth Imam, Fātima al-Ma'șūma (Fātima the pure), whose shrine (figs. 1-3) attracts millions of pilgrims from all over the world every year and determines the sacred identity of the city. ${ }^{24}$ Also worth mentioning is Ahmad b. Mūsā b. Ja'far, known under the name of Shāh-e Cherāgh (King of Light), one of the descendants of the seventh Imam, buried in Shiraz, whose sanctuary is today one of 

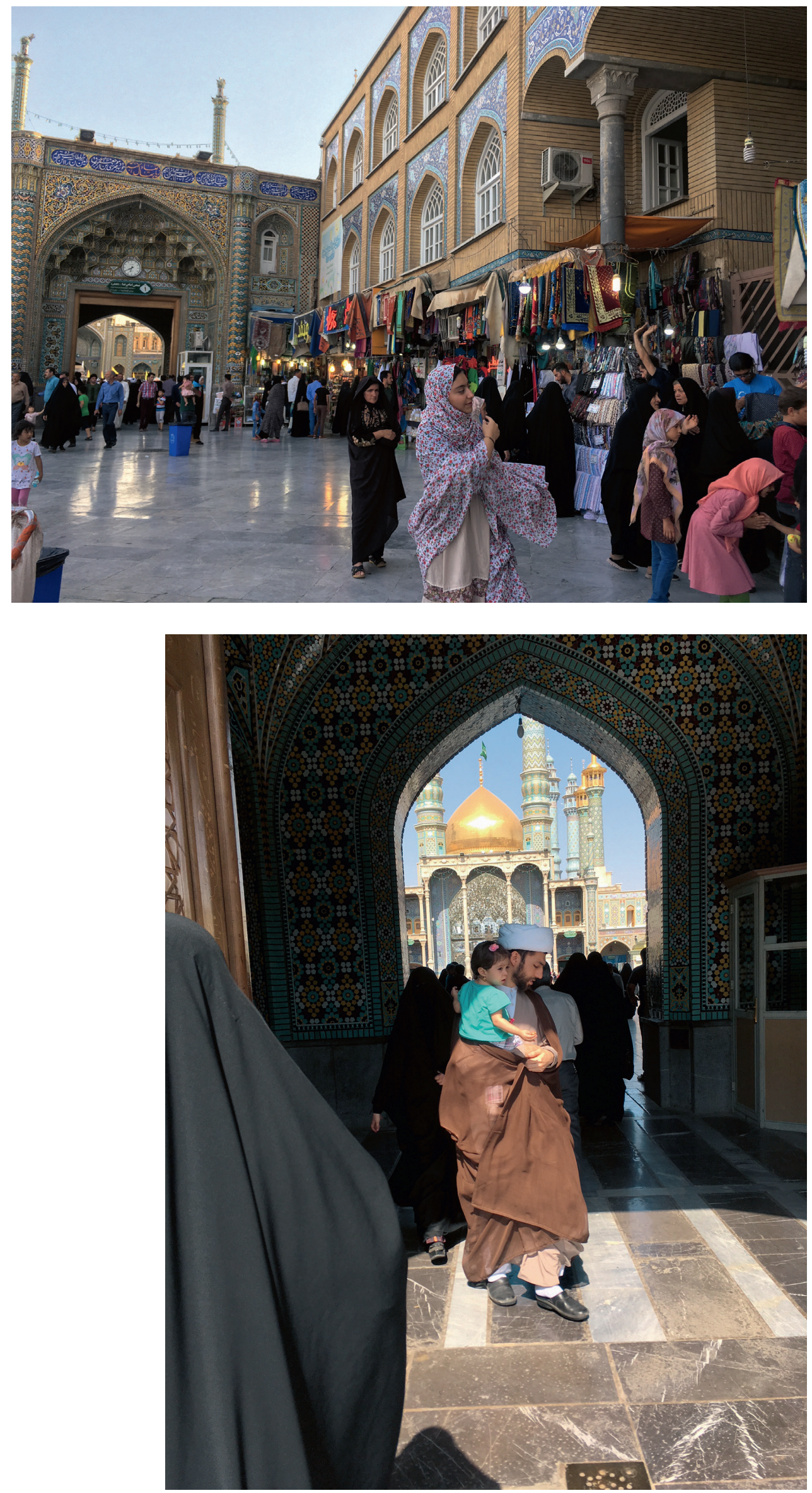

FIGURES 1 AND 2

The shrine of Fātima al-Ma'șuma in Qom

(C) S. PARSAPAJOUH, SUMMER 2017 
FIGURE 3

The shrine of Fātima al-Ma'șuma in Qom

(C) S. PARSAPAJOUH, SUMMER 2017

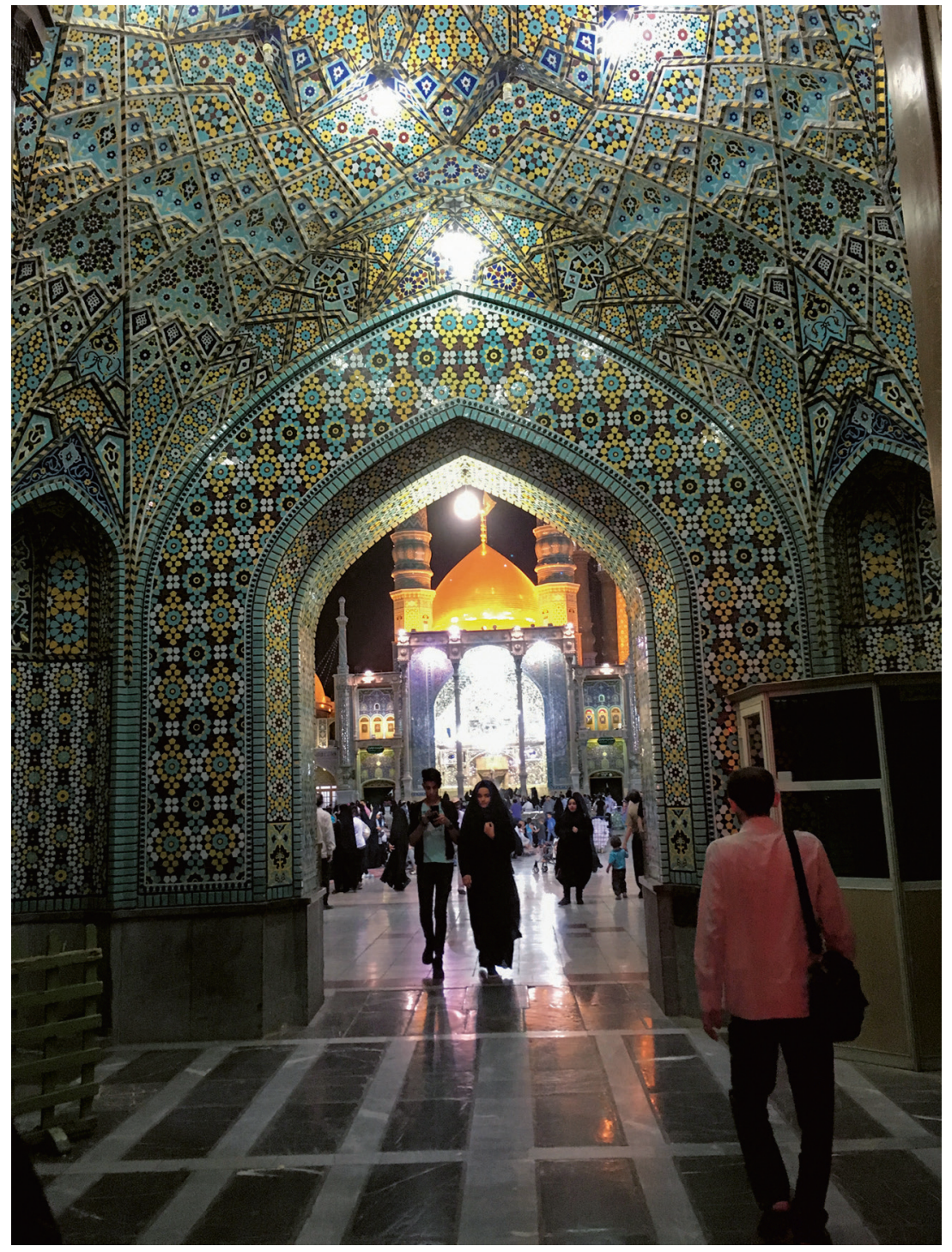

the most attractive monuments both in terms of piety and architecture. Among these figures are very important personalities, such as Abū l-Fażl al-'Abbās (son of Imam 'Alī, half-brother of Imam Ḥusayn, who fell beside him in Karbala), and Sayyida Zaynab (sister of Imam Husayn, a survivor of the tragedy of Karbala), whose shrines we will discuss below. Some of these secondary saints, who are very closely related to the Imams including those mentioned above - are almost as important as the Imams themselves. The others are less important on a macro and transnational scale, and the subject of local cults, of which the most numerous are located on the Caspian Sea in Gīlān (671) and Māzandarān $(1,276)$. How can this be explained? This place, situated between two natural borders: the sea on one side and the Alborz mountains on the other, was perhaps an excellent shelter for those persecuted who sought refuge from Sunni rule in the central regions.

\subsection{The Sacredness through Divine Election: The Holy Prophets}

The third category consists of the prophets: all biblical prophets occupy an important place in the faith of the Shi'a, but some of them are the object of particular pious visits in the places attributed to them by legendary accounts, for example: Idrīs (Enoch) and Ibrāhīm (Abraham), Khiẓr, but also Adam, Nūḥ (Noah), Ṣāiḥ̣ (Salah), and Hūd (Eber). 
These last four have tombs attributed to them in Najaf, at Wādi al-Salām Cemetery, and believers pay pious visits to these tombs. According to the head of the Iranian Organization of Holy Places, the tombs of thirty-three biblical prophets can also be found in Iran, including: Saleh, who has two graves in two regions; Danyal (Daniel) to whom five tombs in different regions, such as Shushtar, are attributed; Khiżr to whom, in addition to numerous places of apparitions, three tombs in three different cities are attributed; Yahyā (Jean the Baptist) to whom a tomb is attributed near Golpaygan; Shu'ayb (Jethro) with two tombs; Jirjīs (Georges) who also has two tombs (in Eastern Azerbaijan in Iran and in Semnān); Ayyūb (Job) with three tombs in three different cities, but also Lot (Lūṭ), Sām, Shayth (Seth), Nūḥ (Noah), Dāvūd (David), Ya'qub (Jacob), Ishmūîl (Samuel), Habqūq (Hubakkuk), etc. One may notice that some of them have several tombs, located in different places (we address the issue of the plurality of tombs below), and on top of each of these tombs, a mausoleum is built. Many locals, people from the region and even the rest of the country go there to carry out their pious and devotional practices, in varying degrees and intensity. It should be noted that these are only examples from Iran, and that it is well known that in the regions surrounding the Mediterranean basin, the places attributed to the biblical prophets are innumerable. ${ }^{25}$

\subsection{The Sacredness through Bloodshed: The Martyrs}

The fourth category of saints contains the martyrs. As we know, given the tragic history of Shi'ism, the sacredness of the martyr's blood is strongly emphasized. Among these personalities we can name the martyrs of Karbala. The most venerable of these saints are Ḥabīb b. Maz̄āhir Asadīi, ${ }^{26}$ buried in the very sanctuary of Imam Ḥusayn; Ḥurr b. Yazīd Rīyāḥ̄i, ${ }^{27}$ buried in Kufa, in a place eighty kilometers from Karbala; Hānī b. 'Urwa, ${ }^{28}$ who is buried in a mausoleum located within the Kufa Mosque complex. Others fought or resisted in the name of truth and the sacred cause of Imams in their absence, and were killed, such as Mukhtār al-Thaqafĩ (1/622-67/687), leader of a revolt to avenge the massacre of Karbala in 684, whose shrine is currently located within the Kufa Mosque compound; ${ }^{29}$ or Maytham al-Tammār Asadī Kūfî (m. 59/679), who was killed before the drama of Karbala, and buried near Kufa Mosque; Kumayl b. Ziyād Nakha'ì, killed in $81 / 701$ (ca) when he was almost 70 years old, whose sanctuary is located in Najaf. Both of them were Imam 'Alī's close companions and were killed because of their loyalty to 'Alī and his two children. In this category, we also have to mention the many martyrs of recent years' wars in Iran, Iraq, Lebanon and Syria, who are all considered, in the local and internal spirit of Shi'a, to be sanctified persons who have defended, in the present time, the sacred cause of the Imams. ${ }^{30}$

\subsection{The Sacredness through Wisdom: The Wise Men}

The final and fifth category of saints is the 'ulama $\bar{a}^{\text {' }}$ or the 'urafă', in other words scholars, jurists, theologians, philosophers and mystics. They are sometimes even considered to be more sacred than the martyrs, in particular according to a famous hadith by the Prophet and Imam Șādiq: "The ink of the wise men ('ulamā) is superior to the bloods of the martyrs (shuhadâa)",31 a sentence that is sometimes inscribed on their tombs, in imitation of Ibn Fahd Hillì (a 14th-15th) in Karbala (fig. 4). But we also have to mention the famous Shaykh Șadūq (Ibn Bābūya, 923-91) in his mausoleum in Rey [the medieval capital city of Rayy in present-day Tehran's southern suburb]. Like 'Abd al-Azịm al-Hasani (173/789-252/866) a great scholar and transmitter of hadiths and one of the descendants of Imam Hasan, whose very important mausoleum is also located in Rayy. A great number of other scholars are also buried around the shrines of Imams, such as Shaykh Mufìd at the sanctuary of Kāzimayn, Shaykh Țūsī, next to the mausoleum of Imam 'Alī in Najaf, etc. These tombs are also visited and revered as holy places. 
FIGURE 4

The tomb of Ibn Fahd Hillī, near the shrine of Imam Husayn, in Karbala. On the border: "The wise men are the heirs of the prophets" - "The ink of the wise men" [is] "superior to the blood of the martyrs".

(C) S. PARSAPAJOUH, SUMMER 2018

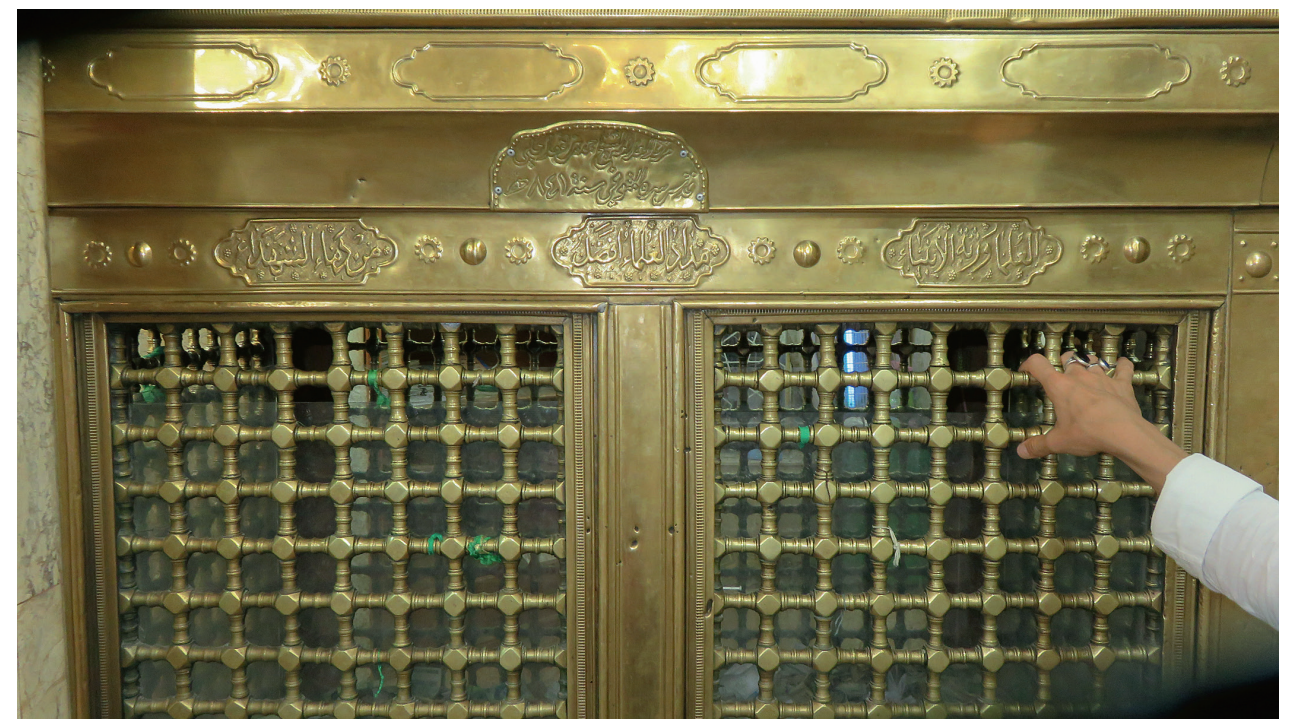

The presence of women in all the saintly categories mentioned above is very important and should be highlighted. They are loved and venerated in varying degrees depending on the importance attached to their beings - and equally by male and female believers.

This typology only schematizes the hierarchy of saints in Twelver Shi'ism; these categories are not tightly sealed. They often intersect: Imams are first and foremost considered to be scholars par excellence, because of their direct access to divine science, all are also seen as martyrs. Similarly, some of the most important martyrs are related to Imams by kinship, and some scholars are also martyrs or relatives of Imams. Science and martyrdom are qualities linked to sacredness: if they are found in one and the same person, then he is a saint par excellence, as embodied by the first Imam, 'Alī b. Abī Ṭālib, but also by all the Imams who are his descendants, known as the perfect men in Shi 'ism.

Saints are loved and venerated by believers in varying degrees. Each believer can form a special bond of friendship (or alliance) with some of them, and sometimes even very intimate relationships develop, especially through dreams and effective influence of the saints on the lives of believers. The personal choice of the Imam or holy man can also be made according to temporary needs linked to the life cycle of the believer (marriages, conception, death). In spite of their multitude and diversity, all these saintly figures are part of the same sacred entity, of the same circle of alliance, the walayya, as explained above.

\section{The Place as Embodiment of the Sacred}

In Twelver Shicism, like in Sufism, the places that are supposed to contain the body, or bodily remains of these sacred figures, constitute the crucial element of devotion because they concretize the sacredness, make it visible, materialize it and, in short, incorporate the saint. It is through the power of the faith in the sacredness of these places that various forms of spatial organization, often entire cities, have been formed around them: they are poles that define the location of other neighboring centers of activity, and constitute crucial political, economic, urban and even scientific points, both nationally and transnationally. 


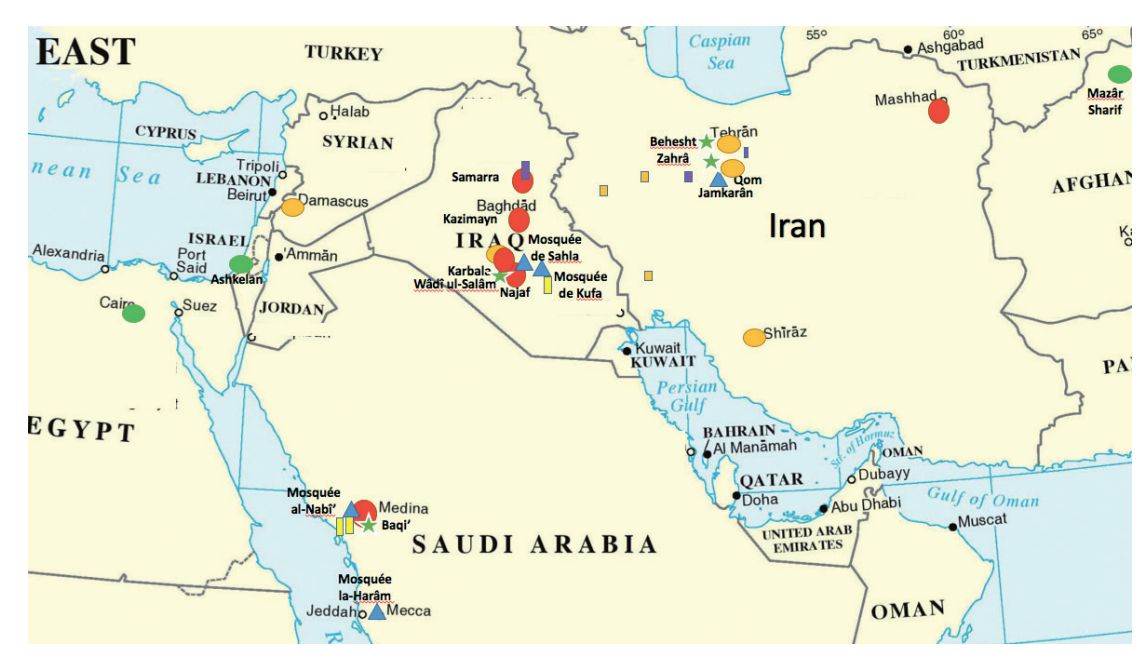

3.1 The Most Important of Sacred Places: The Sepulchre of the Imam

The first type of holy place is, of course, the tomb. Because of the multiplication of sacred figures in Shi'ism, the holy places supposed to contain the bodies of saints or the traces of their bodies, are innumerable. Some of these places are called mashhad, "a place of martyrdom" or "martyr's tomb" (like the name of the Iranian city developed around the tomb of the eighth Imam, a city of 3 million inhabitants today). The words Marqad (Quranic term for "tomb") or mazār ("visited place") are also used. The shrines built around their graves are also called haram or bārgāh (in Persian), which means "safe" and "sacred place".

In the case of an important and highly venerated saint, a cenotaph, a form of empty coffin placed on the saint's grave, often protected by a metal or wooden grid (called $\dot{z}$ arịh in Persian), symbolizes the physical presence of the saint, the power of the body buried. The tomb is supposed to contain relics. But some saints have several graves. More often than not, this is because people from different regions each have their own stories about a saint's fate, as, for example, in the case of Imam 'Ali or in the case of Sayyida Zaynab, which will be discussed below.

\section{$3 \cdot 1.1$}

\section{Where is Imam 'Alì's Sepulchre? Multi-Locality Due to the Divergence of Narratives}

At least two mausoleums claim to preserve the highly sacred body of Imam 'Alī: one is in Najaf in Iraq, and the other in Mazār-e Sharīf, Afghanistan. Both are visited by masses of believers. The reason for this goes back to the history of his death/martyrdom and the tragic events that preceded it: according to historical reports, he was struck on the 19th of Ramadan of the year 40/661 in the Kufa Mosque (10 km from Najaf), and secretly buried according to his own request. The location of his tomb was therefore unknown for a century, until the end of the Umayyad Caliphate (40/661-132/750). Only his children and a few very close companions knew the place of burial. During the Abbasid Caliphate (132/750-656/1258), the place of his tomb was revealed by Imam Ṣādiq, the sixth Imam (d. 148/765). It was during this time, according to the report of the revelation of his tomb by Imam Ṣādiq, that two parallel accounts were reported around the place of his burial. For Najaf, on which the Iranian and Iraqi Twelver Shi'a are unanimous, it coincides with the reign of Saffāh, the first Abbasid caliph (r. 132/750-136/754), or with that of al-Manșūr (r. 136/754-158/775), the second Abbasid caliph. However, in Mazār-e Shariff (the name of the city means "noble tomb"), located $15 \mathrm{~km}$ from the historic Khorāsān capital city of Balkh and nearly 3,00o km away from Najaf, the locals (rather Sunni) believe that the

\section{FIGURE 5}

Map of sacred places in Afghanistan, Iran, Iraq, Arabia, Syria, and Egypte 
body of Imam 'Alī (the fourth of the "well-guided caliphs" according to Sunni creed) lies there. They believe that he was moved from Najaf to this city in the Umayyad period and that he was buried in a place now called Masjid-e Kabūd, "the Blue Mosque". For the Shi'a, according to theological and historical arguments, this cannot be possible. As the history of this second place is lesser known than the first one (Najaf), let's review it briefly here.

Ḥāfiz Nūr Muhammad Kahgedā'̄ī, in his History of Mazār-e Sharīf (Manuscript, 1946), explains the mysterious account of this place. ${ }^{32}$ The beginning of the text is noteworthy; it is a description of the tragic scene of the martyrdom of Imam 'Alī. He writes: "O dear reader! Imagine, thirteen centuries ago, and a few years before that, in the city of Kufa at the foot of the minaret of the Friday Mosque, a resurrectionary passion was taking place. A corpse was rolled up in blood, the corpse of one whose degree of greatness, neither earth (zamin) nor time (zamān) can describe; both of them [earth and time] will be in competition until the end of the universe to do it, in vain. A soul has left this corpse on which [all beings] from the earth to the highest heaven sent light and mercy, and he received it as a beloved soul. And this corpse, is the pure corpse of a person, whose grave and place of burial will be hidden the day after that [event] from everyone except the holders of the secret and the elite (khavās). And Muslims of all ranks, from Najaf to Balkh, from Yemen to Marv, build hundreds of stations (maqām) in his great name; and bow down before his respected name; and imagine being on the land of his threshold [of his sanctuary], they will put their foreheads on the ground (/bow down)." ${ }^{33}$

Then he explains, quoting eight ancient references, that Imam 'Alì's body was buried first in Najaf, but hidden from everyone out of fear of defamation by his enemies. Then he goes on to mention eleven other references of the wise men from the Balkh area, all recounting the story of Imam 'Alī's burial, the transport of his body to Balkh, the discovery of his grave and the history of this place. ${ }^{34}$

Here, the account of the presence of the body of Imam 'Alī in Mazār-e Sharif is based on a hadith attributed to Imam Șādiq, ${ }^{35}$ according to which the body of Imam 'Alī was moved by Abū Muslim Marwazī Khurāsānī (99/718-137/755) to this place. ${ }^{36}$

Abū Muslim Marwazī Khurāsānī rose up against Umayyad power in 128/746, then, according to this account, suggested to Imam Șādiq to accept the caliphate in his region. The Imam rejected this proposition, and instead asked him to bring the body of his father 'Alī [i.e. his ancestor] from Najaf, where he was buried in a chest, to Balkh, in order to protect him from the Umayyad Caliphate. He also asked him to keep the body there, and then to send him to Medina, as soon as the conflicts were over. Hafiz Nūr Muhammad attributes this sentence to Imam Ṣādiq, in his history about Mazār-e Sharîf, as an answer to Abū Muslim by a messenger:

"Of us, the people of effort, everyone who has made an exit (against the ruling power), has reached martyrdom. We, therefore, have no desire to govern, and, no attachment or longing for it"; then before the message leaves for Abū Muslim, Imam asks him to say to Abū Muslim "but if you want to do a valuable service to our family, it would be appreciated if you transport to Balkh, the pure body of my beloved ancestor, which is in a chest and buried in Najaf to Balkh, so when the discord is over and the capital is conquered by our people, transfer him to Madina." ${ }^{37}$

Abū Muslim, who received this request, considered its fulfillment to be equal to his blessing. He then sent most skilled people of 'ayyārān to Najaf, who took the chest and the holy body of the Imam to a hideout, and brought him to the Khorāsān capital city of Marv (Shāh-e Jahān), located near today's Mary in Turkmenistan, on camel's 
back. "Then they take him to a place called Kūh-e Nūr (the Mount of Light). Later, they brought him to Kalf; from there, by the 'water' (Amuyeh), [i.e river Amu-Darya?], they brought him to Balkh, where they buried him discreetly in a village called Khayrān on the Balkh sunny side, and also placed a stone slab with the inscriptions (lawh), containing the truths of the circumstances of the tomb" (p. 29-30).

Because of tensions and wars with the Umayyad Caliphate, the seizure of power by the Abbasids, and the assassination of Abū Muslim, this event and the tomb remained hidden.

At the time of Hārūn al-Rashīd (r. 165/786-188/809), it was revealed to the Caliph that the tomb of Imam 'Alī was in Najaf, so he built a shrine on top of the tomb in Najaf. This is how the burial in Balkh remained concealed.

Nearly four centuries later, during the reign of the Seljuq Sultans, in 524/113o, Sultān Sanjar Malikshāh found a trace of the correspondence between Abū Muslim and Imam Șâdiq. Then, it is believed, that four hundred sādāt (the descendants of the Imams) and wise men of Balkh all, simultaneously, dreamt that Imam 'Alī appeared in the town of Khayrān, and that he asked them to inform the sultan about the location of his tomb. And so it happened; Sulțān Sanjar asked the governor of Balkh to pursue the matter. He traveled to Khayrān, accompanied by his men, despite the dissaproval of the religious authorities of the town, who denied the existence of the body of the Imam in that place. They excavated a hill called tal-e 'Ali, and found a tiny dome with a small steel gate and a silver padlock. They opened it, entered the room, and found a steel chest with an inscription of a Quranic verse written in Kufic script on deerskin, a sword, and a board on which was written: Hazāa qabr wali-Allāh, 'Alī asad Allāh (This is the tomb of God's friend, 'Alī, the Lion of God). They opened the chest and found the pure body of the Imam, intact and fresh. When Sultān Sanjar heard about it, he came to visit the Imam, and donated 50,000 pieces of red gold to bring the body to Marv, but the wise men of the place did not allow him move the body. Instead, he had a small dome built over the grave, the existing tensions and conflicts not allowing him to build a real shrine.

When the Mongols invaded the region in the early thirteenth century, the local people, for fear of defamation of the tomb, destroyed it and made it disappear in order to protect it. This is how it was lost again. In 884/148o, during the reign of Sultān Husayn Bayqarā (842/1438-911/1506), Shams al-Dīn Muhammad found a document in the library of Multan in India (in present-day Punjab) in which the history of the excavation from the times of Sultān Sanjar was reported. He then undertook further excavations, as a result of which the tomb was found. Later, Sulțān Husayn (1047/1668-1101/1726) ordered the construction of a beautiful sanctuary in this place, the one that is still there today, with urban infrastructures, bazaars, canals etc. surrounding the tomb. He sent important families to this place, which in turn encouraged other people to settle there. All of this finally led to the formation of a real city around the shrine, named Mazār-e Sharif.

For contemporary Iraqi and Iranian Shi' i scholars ( faqi h), this story is not very credible, because, according to their laws, the exhumation of the impeccable Imam has been forbidden and it would have been impossible for an Imam (Ṣādiq) to have made such a request. For them, including Ayatollah Mar'ashī (1315/1897-1411/1990), an Iranian expert of the lineages of Imams, this story is a case of mistaken identities: the tomb in question belongs to a descendant of Imam Husayn whose name, father's name and son's name resemble the name of Imam 'Alī. ${ }^{38}$ According to these scholars, the following lineage of another person is confused with Imam 'Alī: Abū l-Ḥasan 'Alī b. Abī Ṭālib Ḥasan b. Abī 'Alī Ubaydallāh b. Muḥammad b. 'Ubaydallah b. 'Alī b. Ḥasan Amīr b. Ḥusayn b. Jáfar Ḥujjat b. 'Ubaydallāh b. Ḥusayn Aṣghar b. 'Alī b. Ḥusayn.

For these Shici scholars, there is no doubt that the real tomb of Imam 'Alī is in Najaf. They have a lot of respect for this place however and believe that the pious visits and 
devotional practices completed there are valid. All people who pray there do this with the intention of worshipping Imam 'Alī, and the Imam can in fact, by his nature, be present everywhere. "Although the story about this place is not authentic, the visits are made in the name of Imam 'Alī, and many, many souls seek intercession there, and all the respect that people have for this place is because of 'Alī, so therefore this place is attributed to him and very venerable" (a young Iranian cleric argues).

\subsubsection{Where Sayyida Zaynab Is Present: From Medina to Cairo?}

Sayyida Zaynab (5/626-62/682), also named Zaynab Kubrā, was the daughter of Imam 'Alī and Fāṭima al-Zahrā, and the sister of Imam Ḥasan and Imam Ḥusayn. She was present at the drama of 'Ashurā. According to the Shi'a, with the role that she played after the Karbala event, she demonstrated the truthfulness of the movement and the commitment of Imam Husayn. She was taken captive after the battle, along with the rest of the survivors (widows and orphans), and brought first to Kufa, then to Sham (Syria). Her talks and eloquent sermons to the Umayyad authorities greatly contributed to the continuation and promotion of the movement of Imam Husayn. According to historical sources, she died in 62/682. It is said that she was buried in a garden belonging to her husband 'Abdallāh b. Ja'far b. Abī Ṭālib near Damascus, where her mausoleum is currently located. This place is one of the most important holy places for the Shica, and known as Zaynabiyya. It has been the subject of major conflicts since the Syrian crisis, starting in 2012. During these conflicts, this place has been the target of attacks by jihadi Islamists. However, a significant number of Iraqi, Afghan and Iranian Shi'a came forward as haram (of Zaynab) defenders against the jihadists in war. For some years now, Iranians have been involved in the reconstruction of this place, which is considered holy, but also geopolitically very important for Iran.

This place is not the only one that is claimed to embrace the body of the Great Zaynab. Another place, more important historically and even more significant from the point of view of sacred history, is located in Cairo in Egypt, in a place now known as the Sayyida Zaynab Mosque. Muhammad Zakī Ibrāhīm reports in his book, The tombs of the Ahl al-Bayt in Cairo, that after her arrival in Medina, after the event of Karbala, Zaynab had to leave this city because of the constraints imposed by the Medina authorities. She then took refuge in Egypt, as the people there were reputed to love the Ahl al-Bayt, and so she died and was buried there in Rajab 62/682. ${ }^{39}$ This place is highly revered since the very beginning of the eighth century CE. During the Qajar period (1200/1786-1343/1925), and throughout part of the Pahlavi period (1343/1925-1399/1979), many Iranian pilgrims passed through Cairo on their way to Mecca to visit this place, as well as other holy places attributed to Ahl al-Bayt in this city. ${ }^{40}$ This must have been the result of the good relations between the governments of Iran and Egypt at that time, which deteriorated after the Iranian revolution of 1979. Did Syria replace Egypt in this respect, and does this also concern the pious visits of Iranian Shi'a today?

Anyway, that is not yet all. There are still other historians who believe that Sayyida Zaynab died in Medina and was buried in the Baqi' ${ }^{`}$ cemetery there, ${ }^{41}$ making it inaccessible for Shi'a, like all the other tombs in this cemetery. We do not have more information about the fate of Zaynab from after the event of Karbala. We do not know which tomb in these three locations is the true one. Each of these places is surrounded by its own socio-political conditions, which determine the pious practices of the devotees. 


\section{2}

The Multi-Locality of the Mausoleums Due to Dismembered Bodies: The Martyrs of Karbala

3.2.1 The Very Venerable Body of Imam Husayn, Is in More than One Place ... Sometimes, a body has been dismembered, transported, and dispersed; its possible burial sites multiply, as a consequence. The bodies of some martyrs of Karbala, like that of Imam Husayn himself, are among them. Various historical accounts and reports circulate about the head of Imam Husayn, and many places all over the world are considered blessed and sacred due to the presence of his venerated head. Some claim to contain it, others claim to keep some material remains (drops of blood) thanks to his ephemeral, sacred presence.

According to the official Twelver Shi'i version of events, the noble head ( $r a$ 's al-sharif) is buried in Karbala. In this version, it is his son 'Alī b. Husayn (imam Sajjād) who has joined the head to the body, forty days after his father's martyrdom. A small minority within Twelver Shi'ism, however, believe that the head is in Najaf, next to his father's body, in Imam 'Alì's shrine. Others think that it is in Medina, at Baqī', next to his mother Fātima al-Zahrā (the daughter of the Prophet). For others, it is in Damascus, in a mausoleum called Ra's al-Sharif where the heads of other martyrs of Karbala, are gathered, situated in the Bāb al-Ṣaghīr's cemetery, or even in Aleppo or in Raqqa, in Syria. Some historians believe that the sacred head is buried even farther from his body: in Cairo, inside a Fatimid mosque that bears the name of the head Ra's al-Husayn. ${ }^{42}$

There are also places that are supposed to have kept it for a shorter period, and they have become places of veneration because of it. The Hannana Mosque near Kufa is one example: the venerated head is supposed to have been in this place for a short while only, after the drama of Karbala, when the captives were on their way to Kufa. But let us not forget the Umayyad Mosque in Damascus, the iconic place where the head was placed before the Caliph Yazīd b. Mu'āwiya, to whom Zaynab, the Imam's sister, gave her famous speech denouncing the Caliph. These places, which bear a material (blood?) or even invisible trace of the short presence of this highly venerated head, are no less important than the tombs containing real bones.

A very interesting story about a more recent discovery of such a place associated with the venerated head by the Davoodi Bohra in Israel, Ashkelon (Asqalān), demonstrates the degree of this importance.

Ibn al-'Imrānī (seventh/thirteenth century), Zakariyyā Muhammad Qazwīnī (seventh/thirteenth century), and also Ibn Bațūța (eighth/fourteenth century), all wrote about a shrine located in Ashkelon (near today's Gaza strip), containing the head of Imam Husayn, visited by Shi'a. This place is said to have been destroyed in 1950 by the Israeli state, and a hospital, "Barzilai Medical Centre", was built in this location in 1961. In 20o8, Muhammad Burhān ad-Dīn, the fifty-second Da`ī Muțlaq of the Dawoodi Bohra, visited the hospital and requested his vice-president to build a prayer room on this site (fig. 6). The hospital officials who were unfamiliar with the story about the shrine, joined him when he tried to find it on their grounds, started digging in the location that the religious leader indicated, and finally found the foundation of the building of the ancient sanctuary. They then accepted the evidence, and gave this worshipper of Imam Husayn permission to erect a small construction. For this purpose the Davoodi Bohra sent marble from India and built a place of devotion which has been in use on the grounds of the Israeli hospital ever since. At different times each year, groups of Davoodi Bohra travel from India or Pakistan to Israel to make their pious visits to Imam Husayn, in an atmosphere of peaceful coexistence with the hospital staff.

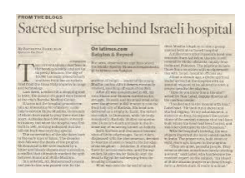

FIGURE 6

A newspaper article about the discovery of the place attributed to the venerated head of Imam Husayn in Ashkelon.

Los Angles Times, 21 May 2008 HTTPS://WWW.LATIMES.COM/ ARCHIVES/LA-XPM-2008-MAY -21-FG-MOSQUE21-STORY.HTML 
FIGURE 7

The Shrine of 'Abbās in Karbala (C) S. PARSAPAJOUH, SUMMER 2018
3.2.2 … As Well as the Sacred Body of His Half-Brother, 'Abbās

The body of Husayn's half-brother, Abū l-Fażl al-'Abbās, rests in Karbala in a shrine (fig. 7), 300 meters away from the Husayn shrine, while his severed hands are located in two other burial sites in Karbala. These places are called maqām, one for his right hand, and the other for his left hand, and they are far removed from each other and can be found in the alleys of the old urban construction arround the two sanctuaries
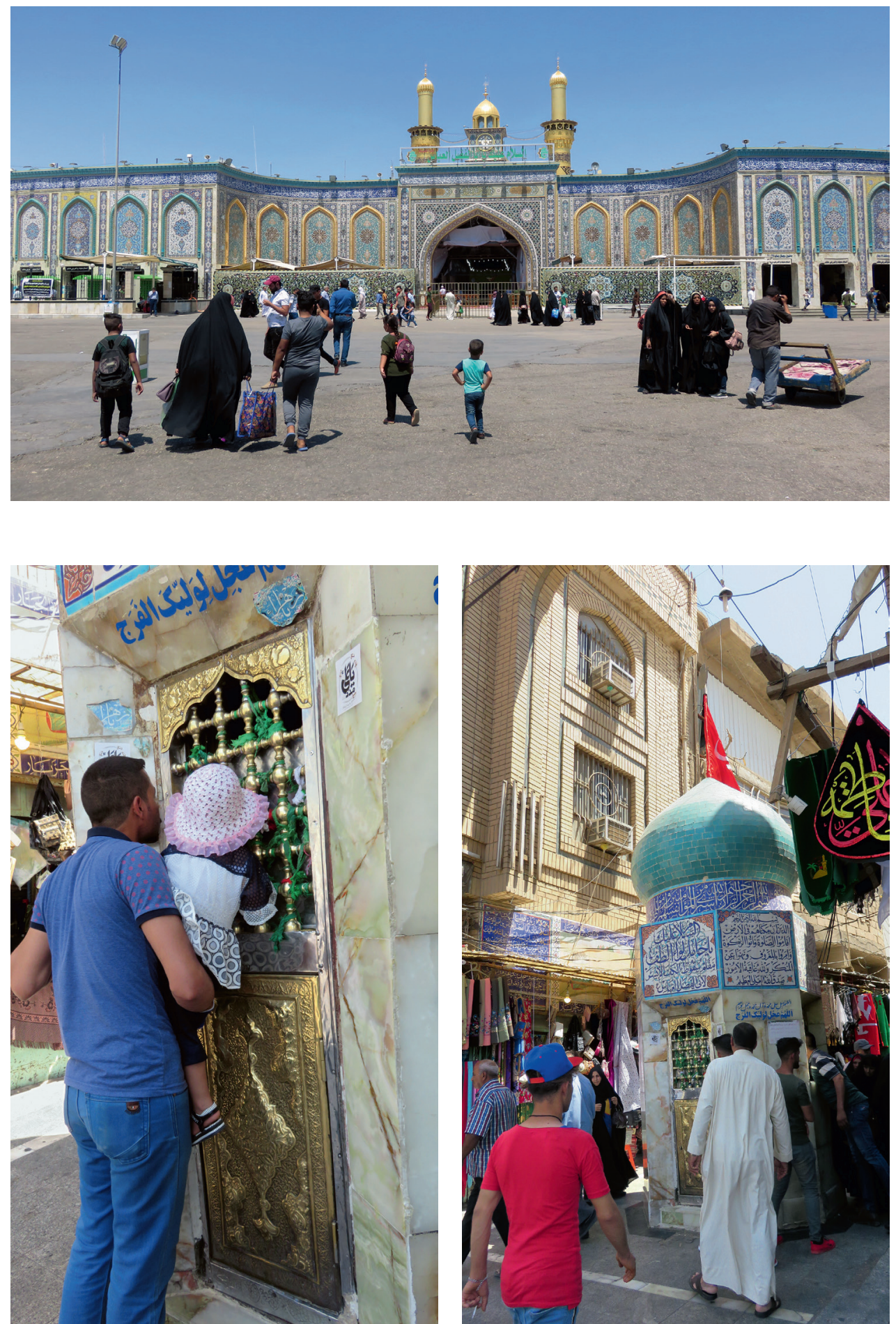

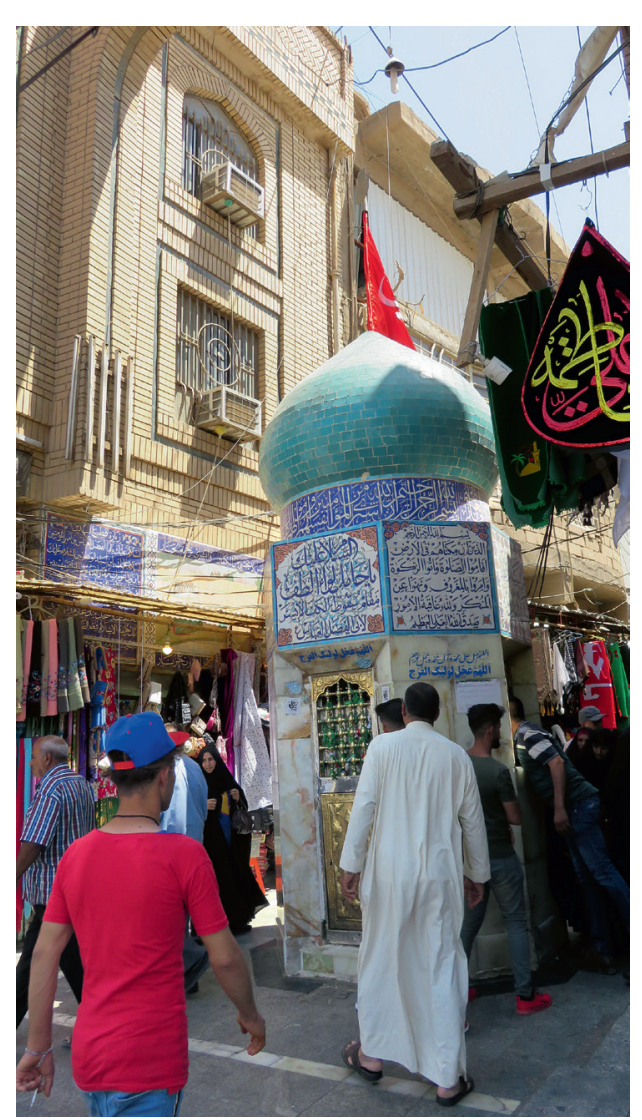

FIGURES 8 AND 9

The maqām of 'Abbās' left hand, in Karbala

(c) S. PARSAPAJOUH, SUMMER 2018 


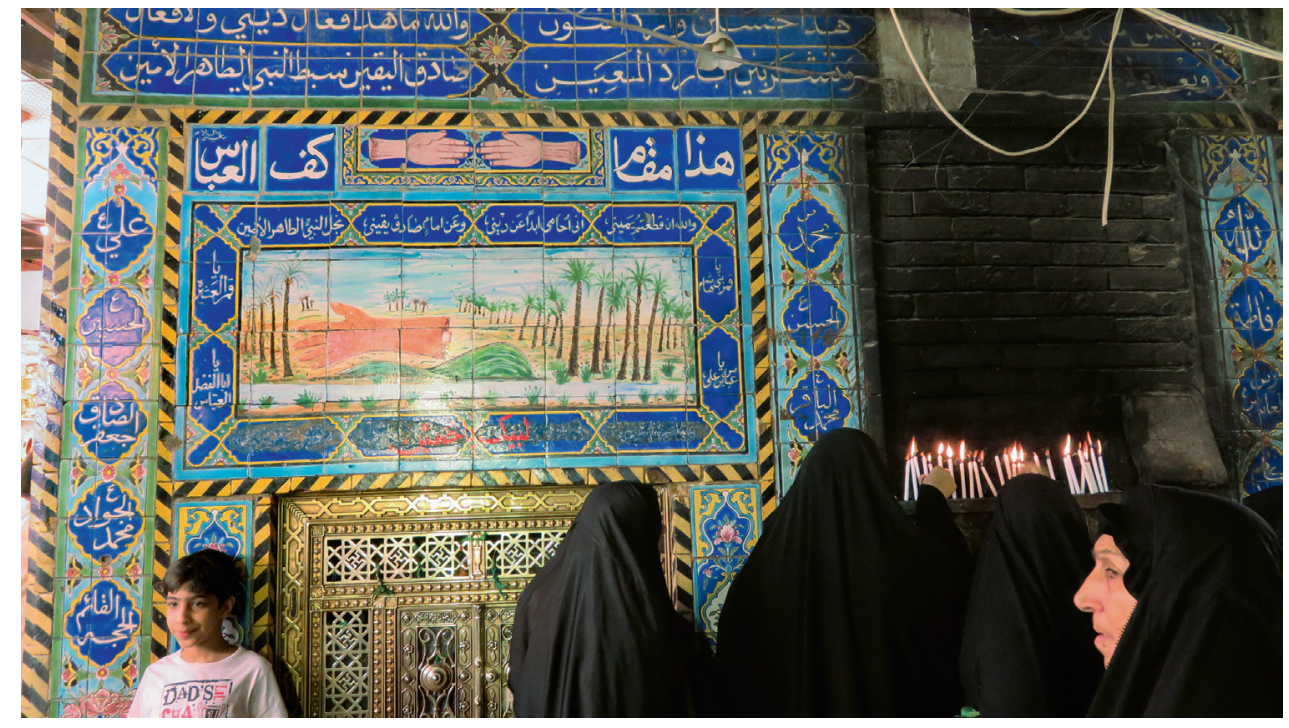

(fig. 8-10). His head, according to some accounts, is also buried elsewhere, much further away in the cemetery of Bāb al-Ṣaghīr of Damascus, next to the heads of other martyrs of Karbala, in a mausoleum that we discussed earlier.

This pluri-location does not disturb the believers in their pious visits. What matters is the spiritual bond that the visitor establishes with the saint. The place is only a support, a means of connection between the pilgrim's soul and the Imam, who is considered to be truly present, watching and acting, responding to sincere requests, wherever the worshippers may be, and independently of scholarly considerations of the authenticity of the mausoleum.

The most important shrines, which attract tens of millions of pilgrims from all over the world every year, despite all the regional problems and conflicts, are actually in Karbala $^{43}$ (fig. 11-12), in Najaf, ${ }^{44}$ in Kāẓimayn and in Sāmarrā in Iraq, and in Mashhad and in Qom ${ }^{45}$ in Iran. More than 28 million pilgrims visited Mashhad in 2017. Some shrines have been, or still are, inaccessible due to violent conflicts and direct or indirect clashes between Shica and Sunnis: the graves of four Imams in the Baqi``cemetery, for example. Karbala was almost inaccessible to Iranian Shi'a under Saddam Hussein's regime. The Sāmarrā shrine was hit by different attacks and only became accessible again in March 2018. The shrine of Sayyida Zaynab near Damascus has been inaccessible since the beginning of the war in Syria.

\subsection{The Territories of the Dead as the Whole Sacred Fields: The Case of Three Memorial Cemeteries}

A cemetery is generally considered sacred in Islam, but there are a few cemeteries which are considered to be particularly holy. They are regularly visited by pious Shi'a. Here we mention only three of them:

1. The very sacred cemetery of Baqi' in Medina, already mentioned. It is the oldest Muslim cemetery, which has in its midst the tombs of four Imams (the second, Hasan, the fourth, Sajjād, the fifth, Bāqir, and the sixth, Șādiq), and also one of the places supposed to house the tomb of Fātima al-Zahrā, the daughter of the Prophet. For the Shi'a, this is a place of pain, as the tombs and mausoleums were destroyed and are now completely inaccessible to them.

2. The cemetery of Wādi al-Salām in Najaf, Iraq, a huge necropolis adjoining the sanctuary of Imam 'Ali (fig. 13-14). It is said that it was the Archangel Gabriel who gave it its name, meaning "the land of safety." According to a hadith attributed to Imam 'Alī: "this
FIGURE 10

The maqām of 'Abbās' right hand, in Karbala

(C) S. PARSAPAJOUH, SUMMER 2018 
FIGURE 11

A khādem of Imam Husayn's shrine

(C) S. PARSAPAJOUH, SUMMER 2018

FIGURE 12

Interior of Imam Husayn's shrine in Karbala

(C) ALIREZA HESAMĪ-NEJAD, 2012
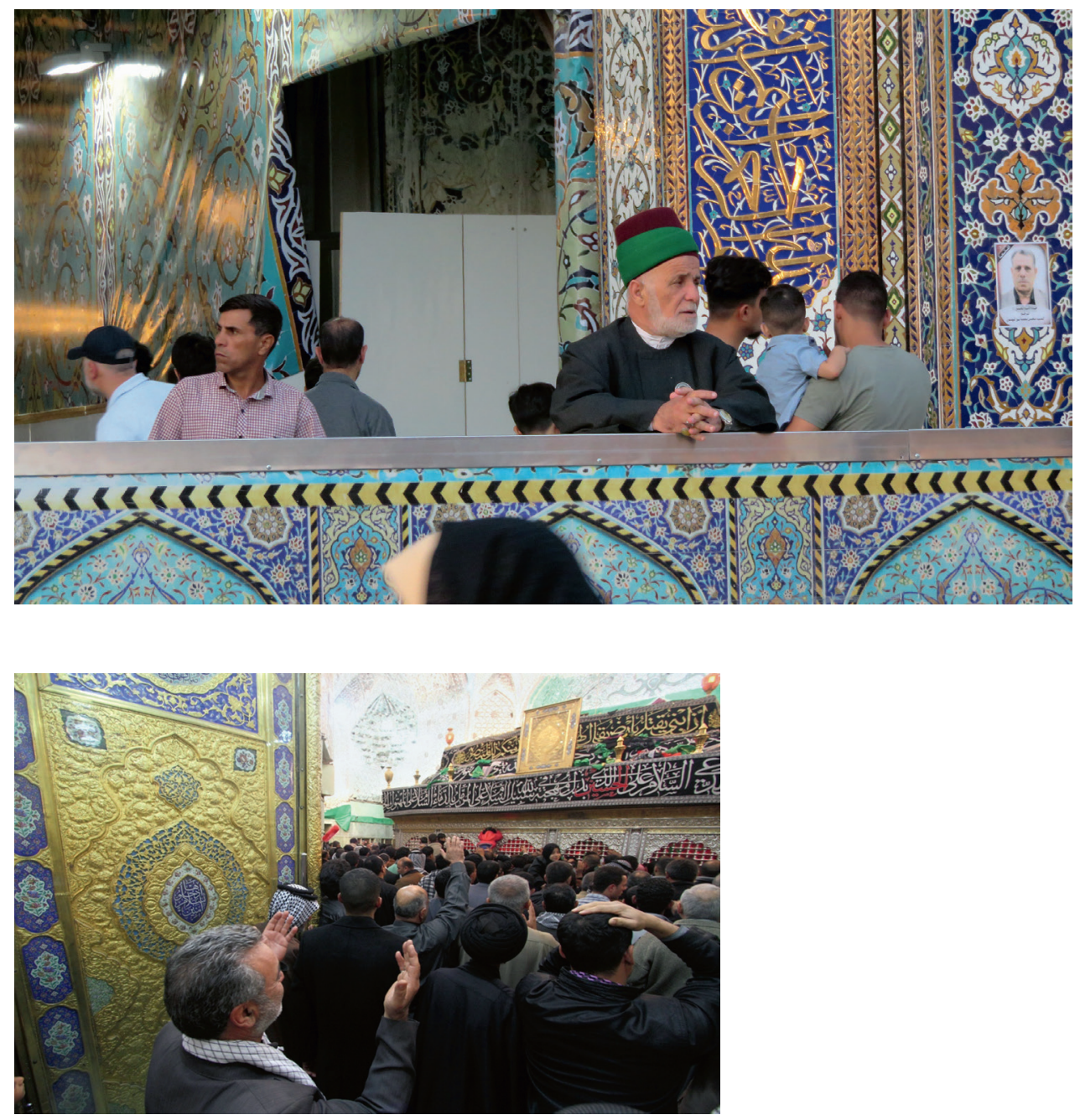

is the first place where God was worshipped. And when God asked the angels to bow down before Adam, that is where they did it." ${ }^{\prime 4}$

It includes tombs attributed to the two Prophets Șālih and Hūd (mentioned above), but also two "stations" (maqām) attributed to the Mahdi and to the sixth Imam, Ṣādiq. This cemetery is also known, according to canonical sources, to be the scene of apocalyptic events that will signal the return (raj'at) of those who will return at the end of times to fight evil alongside the Mahdi, notably Jesus, Muhammad and 'Alī. It is believed that everyone who is buried here will be spared suffering and punishment in the afterlife. ${ }^{47}$ Today the place is extremely active. Countless Shici scholars, theologians and mystics from different periods have visited it with varying degrees of devotion. Many martyrs of the war against ISIs (Islamic State of Iraq and Syria) have been buried there in recent years (fig. 15). It is a place where every fervent Shici believer would like to be laid to rest, after her or his death.

3. The cemeteries of the city of Qom are also considered to be very sacred (fig. 16). Nearly 270 descendants of the Prophet Muhammad, children and grandchildren of Imams, officially recognized as Shici saints, are buried in this city and the object of devotional practices. Among them, is the tomb of Fātima known as Ma'ṣuma, ${ }^{48}$ which brings forth much of the sacredness of the city (fig. 1-3). Over time, it has become the main destination for all national and international pilgrims and it was the origin of the foundation of the first religious school in Qom. This tomb has become the most important shrine over the course of time, as the city rose up around it. Today, the shrine attracts 

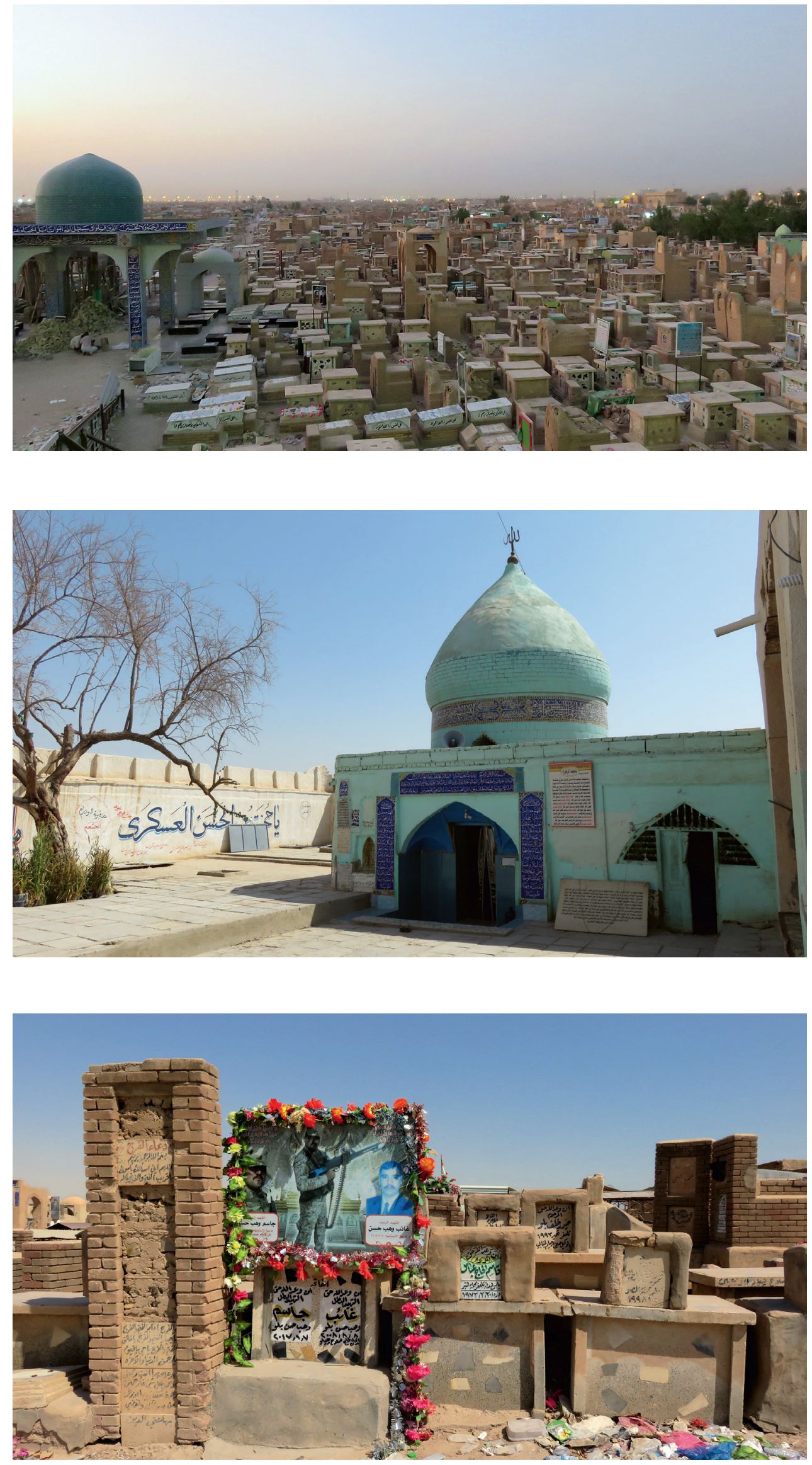

FIGURE 13

Wādi al-Salām cemetry

(C) S. PARSAPAJOUH, SUMMER 2018

FIGURE 14

Maqām of Mahdi in Wādi al-Salām

(C) S. PARSAPAJOUH, SUMMER 2018
FIGURE 15

Example of the martyrs' tombs in Wādi al-Salām

(C) S. PARSAPAJOUH, SUMMER 2018 
FIGURE 16

A part of the Shaykhān cemetery in Qom

(C) S. PARSAPAJOUH, 2016

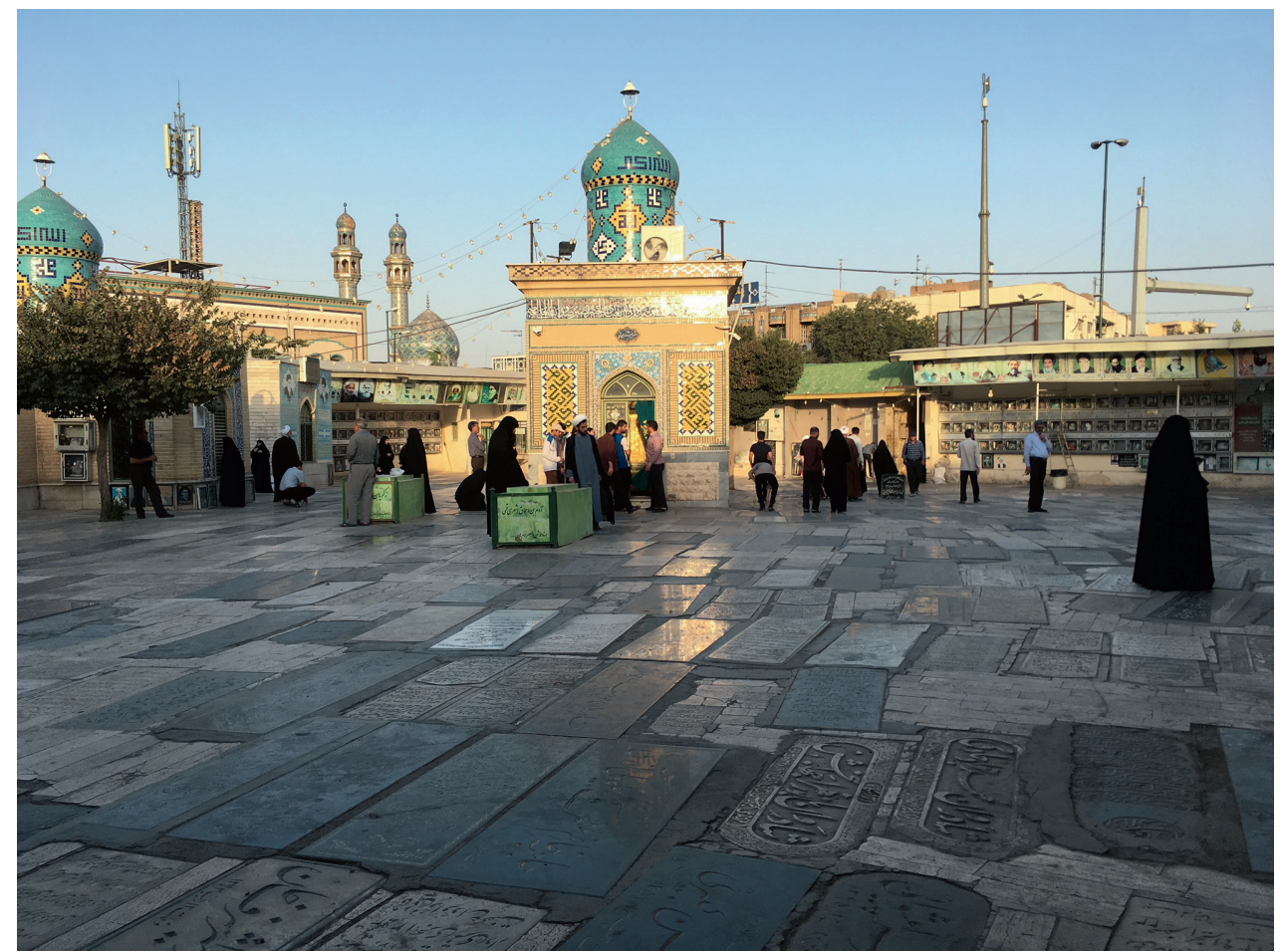

not only crowds of the living - nearly 20 million pilgrims a year - but also crowds of the dead. Countless pious Shi'a request a resting place within the enclosure of the mausoleum, in the courtyard, or further inside the city, to be wrapped in the grace of Fāțima al-Ma'șūma as they enter the afterlife, protected by her intercession on the Day of Resurrection. ${ }^{49}$ The territory of Qom is therefore that of tombs and cemeteries. It was already so before it became a real urban center. As in Najaf, the sacredness of this area has attracted the bodies of the most pious Shi'a since the first centuries of Islam. In the oldest images of the city (sketches, paintings and photographs) the number of graves alongside the mausoleums is striking. According to travel accounts, this landscape lined with tombs was most impressive in the eyes of westerners. Today, it is impossible to tell if it is the sacredness of the city that makes the cemeteries sacred, or the sacredness of the cemeteries and tombs that makes the city holy.

Anyway, this town with its cemeteries is an example of an ancient Shici town, which became holy by the strength of the bodies of the pious people buried there through the ages.

\subsection{When Divine Men Sanctify the "House of God": Some Specific Mosques}

Another category of Shici holy places that should perhaps be mentioned quickly are those that are attributed to saints without any claims that they contain relics. They also receive mass visits. Their sacredness derives either from the temporary and passing presence of an Imam or prophet, or from an essential value attributed to them. First of all, there are the mosques. A mosque, as everyone knows, is generally seen as "the house of God" in Islam, but it is usually not a place of pious visit. However, there are important exceptions. The essential sacredness of two mosques, Masjid al-Harām in Mecca and Masjid al-Nabì (the Mosque of the Prophet) in Medina (where the tomb of the Prophet is located), is recognized by all Muslims, both Shici and Sunni.

The Kufa Mosque has a sublime value for Shi'a only though. It is located $10 \mathrm{~km}$ away from Najaf, and at the center of many historical, hiero-historical (holy history) and 
apocalyptic stories. Historically, Kufa was one of the first garrison towns of the Arab Muslim conquerors of Mesopotamia. It was in this city that Imam 'Alī established his government during his short-lived caliphate $(35 / 656-39 / 660)$; it was in this mosque that he delivered many speeches and prayers recorded by the Shica; and it was here that he fell as a martyr, beaten to death while praying. In the holy history of the Shi'a, Kufa is a real crossroads. In a hadith, Imam 'Alī says about his mosque:

This mosque is the house of Adam, the house of Noah and Idris, the place of prayer of Abraham, the place of prayer of my brother Khiżr, and today it is mine (...) One day it will be the place of prayer of the Mahdī, of my descendants and the place of invocation of all believers ( $\mathrm{mu}$ 'min $)^{50}$

The compound of this mosque includes many stations called maqām, attributed to prophetic and Imamī figures who are believed to have passed through here during their earthly existence, which visitors honor with prayers. These are the maqāms of Adam, Khiżār, Noah, Abraham, Muhammad, the Archangel Gabriel, and the Fourth and Sixth Imams. It also houses the tombs of three martyrs of Shici history, linked to the drama of Karbala, three tombs to which a room and a żarịh (cenotaph), similar to those of the Imams, are consecrated. One of these martyrs is Mukhtār al-Thaqafĩ (mentioned above). The Kufa Mosque is therefore the site of many ritual visits, including invocations, prayers and religious instruction sessions. Finally, it is believed that this place will be one of the places of the reappearance and sovereignty of the Mahdi, at the end times.

Next is the mosque of Sahla, near Kufa. It is another mythical place for the Shi'a. It is believed to have been the home of four prophets (Abraham, Idris, Khiżr, Șāliḥ), and the place of invocation of three Imams (Șādiq, Sajjād and Mahdī). To each a mị̣rāb is dedicated, the niche oriented towards Mecca before which pilgrims perform prayers. According to the beliefs and words of pilgrims, "there is no prophet who did not pray in this mosque." However, its importance is mainly eschatological, because it is here, according to many, that the Mahdi will reappear at the end times. According to pilgrims, this mosque is one of the two places where all wishes will be granted (the other is the shrine of Imam Husayn in Karbala).

Finally, a few words on the Jamkarān mosque, in a village near Qom in Iran (fig. 17-19). This place has existed since the tenth century, shortly after the Major Occultation of Mahdī (329/941). It is said to have been built after the appearance of the Mahdī to a pious man who commanded him to build a mosque on this land that is sacred to God. A mihrāb here is attributed to the Mahdī, and the courtyard includes a sacred well into which pilgrims throw letters addressed to the "Lord of Time." The village has expanded and urbanized around this mosque. It is believed that the twelfth Imam is present here in person from time to time, anonymously, to observe the pilgrims, to converse with them and to answer their prayers. ${ }^{51}$

All these mosques, because of their geographical proximity to major Shici shrines, attract millions of pilgrims each year.

Apart from these large mosques, there are also modest holy places attributed to sacred figures. These are houses: for example, the house of Imam 'Alī, next to the Kufa mosque, where his well is located, or the house of Fāțima al-Ma'șūma in Qom. And there is the underground gallery in Sāmarrā, which is venerated as a place of birth of the Mahdi and a place of meditation for his father, the eleventh Imam. Elsewhere, in the mountains and in natural refuges, there are places that keep the memory of the passage of a saint through a foot print, such as Khiżr's qadamgāh (the place of footsteps) around Qom. ${ }^{52}$ 
FIGURE 17

Mosque of Kamkarān (C) S. PARSAPAJOUH, 2016

FIGURES 18 AND 19 Jamkarān Mosque: on the left: the space outside the sacred monument, inside the courtyard; on the right, the famous ex-voto well located behind the main mosque

(C) S. PARSAPAJOUH, 2014-2016
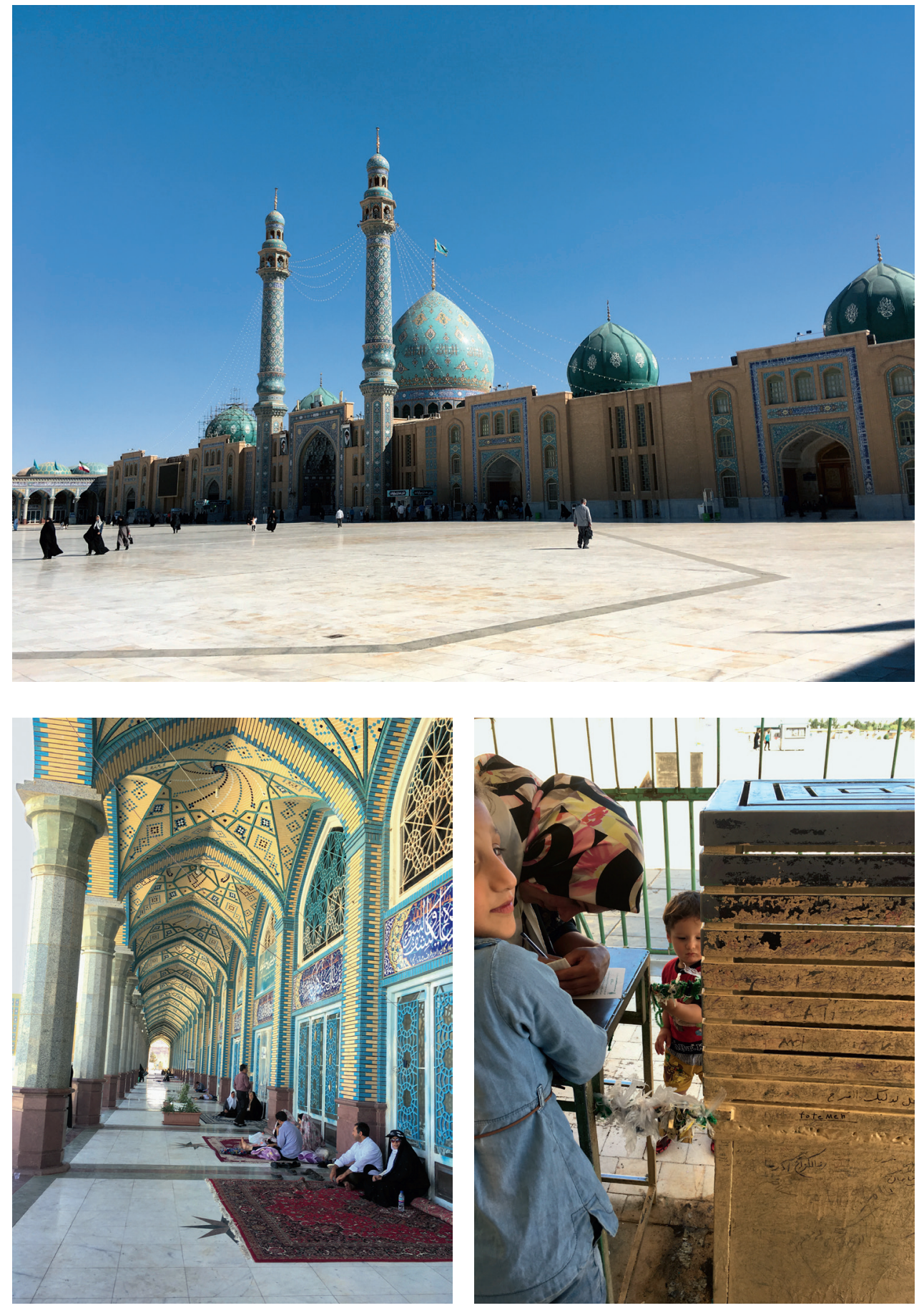

All the places mentioned here are only examples of Shici holy places, there are many others, in other places and towns ...

\section{$3 \cdot 5$}

Can Holy Places Be Everywhere? From the Shrine to the Pocket, the Hand and the Heart!

Returning to the question of places, I must also quickly mention the existence of substitutes, which constitute in fact the symbolic spaces or objects that represent authentic holy places in different parts of the world, especially when access is difficult or impossible. ${ }^{53}$ Examples are the replicas of Karbala scattered throughout the Indo-Pakistani world; the countless Husayniyyas, and places of commemoration of the martyrdom of 
Ḥusayn, which are found in every city and village in Iran. Texts of pious visits, called ziyārat-nämeh, can be substitutes for the visit itself. Likewise, small quantities of Karbala earth, ${ }^{54}$ bits of cloth that have been in contact with the tomb of a saint, or pocket icons can be used as media for visits and spiritual visions. ${ }^{55}$

So, we have seen how devotional practices, concretely linked to bodily remains, i.e. places/tombs, can also be undertaken on an imaginary and abstract level. Millions of believers physically visit shrines, tombs, monuments, parts of a city or an entire city, in order to connect their "bodies" to the "body" of the Imam, to receive through these bodies, a sublime and divine sacredness. In these places, the rituals engage both the body of the saint (the physical remains of his or her body), and the body of the believers. But, as we have seen, these places may contain not more than a few tiny particles left by an ephemeral passage of saints; they may even contain nothing at all. And this is precisely what is so remarkable, because it is a fact that all pilgrims are aware of this, and it does not disturb them. In these concrete places, beyond the reality that the bodily remains of the saint are present or not, the believer considers the saint to be actually present. This presence is what the believer invokes, through 'matter' and 'material' of the place. This place, whether it is a large and important monument, or a small and simple object (including substitutes, such as piece of a text, a pocket icon, or even a handful of dirt), does not really matter, because it is only expected to be a material means of connection. The essential thing is that the object or place promotes the encounter with the saint and his divine being, if even for a moment. Since the saint exercises his supernatural power beyond the material world and spatial locations, a multiplicity of media can make this encounter possible.

We have also seen the importance of various places. Each of them with their own history, bears a part of Shi'i memory and carries a particular meaning in the believers' faith. Most of these places have been the object of destruction, looting, reconstruction, and redevelopment, and, now more than ever, of colossal expansion. The urban planning, and economic, political and geopolitical stakes of the management of these holy places that concentrate the faith of tens of millions of faithful people and pilgrims every year, are very important in the current context of the Middle East.

Beyond the past and present turmoil of history, these places are and will remain, beacons of Shica consciousness and landmarks for believers, whether they are actually accessible or spread throughout the world in the imagination of believers, by traces left objectively or subjectively, or by substitutes. They continue to play the role of supports, linking earth to heaven, bringing about the encounter between humans and the divine through the holy ones. And even beyond these places, as a pious man once told me, "the true sanctuary of the divine, it's fair to say, is the heart of the believer, it is the true throne of God (or of the Most Merciful)" (qalb al-mu'min 'arsh al-rahmān). The Imam is thus a whole omnipresent being, who can be constantly present everywhere, from the outermost sacred place and physical sanctuary, to the most secret and inner place: the heart of the believer. This is where we reach the dual essence of Shicism: a religion that is apparently as comfortable in its relationship with the body and the object, as it is with the secret, hidden, and occult.

\section{About the Author}

Sepideh Parsapajouh is an anthropologist and a CNRs research fellow at the Centre d'études en sciences sociales du religieux (CéSor-EHEss). Her first research focused on an Iranian slum where she uncovered an order based on various solidarity mechanisms. This led her to the examination of immaterial value systems and religious beliefs it that are balanced in a society. Today, she studies various aspects of popular Shi'ite religion, 
individual and collective, intimate and spectacular, in Iran and beyond, in particular practices related to death, devotion, and the worship of saints and martyrs. She is the author of Au coeur d'un bidonville Iranien, Paris, Karthala, 2016; " Sous le regard des martyrs à Téhéran ", l'Homme, n 229, 2019, pp. 7-48; « La châsse de l'imam Husayn. Fabrique et parcours politique d'un objet religieux de Qom à Karbala », Archives des sciences sociales des religions, $\mathrm{n}^{\circ}$ 174, 2016, pp. 49-74 (among others).

Emails: sepideh.parsapajouh@gmail.com; sepideh.parsapajouh@ehess.fr

\section{Bibliography}

Aigle, Denise (2000). Miracle et karāma, hagiographies médiévales compares. Paris: EPHE.

Amir-Moezzi, Mohammad Ali (1996) Jamkarān et Māhān: deux pèlerinage insolite e Iran. In: Amir-Moezzi, ed., Lieux d'islam. Paris: Autrement, pp. 154-167.

Amir-Moezzi, Mohammad Ali (2007). Le guide divin dans le shiisme originel. Paris: Verdier, p. 215.

Amir-Moezzi, Mohammad Ali (2008). Les icônes portatives dans l'imamisme moderne et contemporain. In: Pedram Khosrownejad, ed., Nouvelles approches de l'art populaire Shiite, Cahiers des Studia Iranica 19, pp. 65-89.

Amir-Moezzi, Mohammad Ali (2018). La preuve de Dieu. La mystique Shi'ite à travers l'oeuvre de Kulaynī I $X^{e}-X^{e}$ siècle. Paris: Cerf.

Amir-Moezzi, Mohammad Ali (2021 forthcoming), « Prière de pèlerinage englobant » (al-ziyāra al-jāmi'a) (Aspects de l'imamologie duodécimaine XVII), in : Raison et quête de la sagesse. Hommage à Christian Jambet, sous la direction de M.A. Amir-Moezzi. Brepols: Turnhout.

Amri, Nelly and Gril, Denis, eds. (2008). Saint et sainteté dans le christianisme et l'islam. Le regard des sciences de l'homme. Maisonneuve \& Larose.

Amri, Nelly (2019). Croire au Maghreb médiéval. La sainteté en question. Paris: Cerf.

Andezian, Sossie (2001). Expériences du divin dans l'Algérie contemporaine. Adeptes des saints de la région de Tlemcen. Paris: CNRs Editions.

Bémont, Fredy (1969). Les villes de l'Iran. The cités d'autrefois à l'urbanisme contemporain. Paris.

Boissevain, Katia (2006). Sainte parmi les saints. Sayyda Mannūbiyya ou les recompositions cultuelles dans la Tunisie contemporaine. Paris: Maisonneuve et Larose.

Boivin, Michel (2019). The Hindu Sufis of South Asian. Partition, Shrine Culture and the Sindhis of India. London: I.B. Tauris.

Boivin, Michel (2020). Sufism and Shi' ism in South Asia: Shahādat and the Evidence of the Sindhi marthiya. In: Denis Hermann and Mathieu Terrier, eds., Shici Islam and Sufism: Classical Views and Modern Perspectives. London: I.B.Tauris, pp. 225-54.

Chabert-Loire, Henri and Claude Gillot, eds. (1995). Le culte des saints dans le monde musulman. Paris: Ecole française d'Extrême Orient.

Chatelard, Géraldine and Mervin, Sabrina (2019). Arbaïn, un pèlerinage sous tension. Orient XXI, online.

Chiffoleau, S. and Madoeuf, A., eds. (2005). Les pèlerinages au Maghreb et au Moyen-Orient. Espaces publics, espaces du public, Beirut: L'Institut français du Proche-Orient.

Chodkiewicz, Michel (1995). La sainteté et les saints en Islam. In: Henri Chabert-Loire and Claude Gillot, eds., Le culte des saints dans le monde musulman. Paris: Ecole française d'Extrême Orient, pp. 13-23.

Corbin, Henry (1993). Face de Dieu, face de l'homme. Paris: Flammarion.

Delage, Rémy (2016). Soufisme et espace urbain. Circulations rituelles dans la localité de Sehwan Sharif. In M. Claveyrolas and R. Delage, eds., Territoires du religieux dans les mondes indiens. Parcourir, mettre en scène, franchir, Paris: Editions EH Ess, coll. Purusartha, n 34, pp. 149-75.

Dionigi, Albera and Pénicaut, Manoël (2017). Coexistences. Les lieux saints partagés. Coédition Musée des civilisations de l'Europe et de la Méditérranée (mUсEM), Actes-Sud-Beaux-Arts. 
Harawī, 'Alī b. Abī Bakr, (1214). Al-Ishārāt Ilā al-Ma'rifat al-Zīyārāt, (611 h.l.), Al-Thaqafiya al-Dīnīya (1423, h.l./2002), Cairo.

Hylén, Torsten (2018). Myth, Ritual, and the Early Development of Shici Identity. Intellectual History of the Islamicate World 6, pp. 300-31.

Ibn Qūlūya al-Qummī, Abū al-Qāsim b. Jacfar, (1998), Kāmil al-Zīyārāt, Téhéran, Payām-e Haqq (1377 h.s.).

Ibrāhīm, Muhmmad Zakī (2003). Marāqid Ahl al-Bayt fì al-Qāhira, ed. Ḥasan Yūsuf Asnawī, Mu'assisa Ihyā̄ al-Turāth al-Sīfì, (available online: https://books.rafed.net/view.php?type=c _fbook\&b_id=2470 - consulted: 26.05 .2020$)$.

Ja'farīyān, Rasūl (2000). Panjāh safar-nameh-i Qājār. Volume 8. Tehran: Nashr-e 'Ilm.

Kahgedā'̄̄, Hafiz Nūr Muhammad (1946). Tārikh-e Mazār-e Sharīf. Vāghe` Balkh (lithograph of manuscript: Bāzār-e Katāb-forushi-ye Kabul, (1325 h.s.), available online: https://ia801904 .us.archive.org/21/items/TarikhEMazarEShareefFarsi/azu_acku_ds375_m38_kaaf98_yaa135o _w.pdf - consulted: 04.05.2020).

Kaf'amī (al-), Ibrāhīm b. 'Alī (1982). Al-Misbāḥ. Beirut: al-A'lamī.

Kulaynī (al-), Shaykh Muhammad (2008). Ușūl al-Kāfí. Volumes 1-4. Qom: Qā̄im Āl-e Muhammad.

Majlisī, Muḥammad Bāqir (1982). Bihāar al-anwār. Volume 11. Beirut: Mu’assasat al-Wafā’.

Mervin, Sabrina (2010). La quête du savoir à Najaf. Les études religieuses chez les chiites Imamīs de la fin du $19^{\mathrm{e}}$ siècle à 196o. In: Denis Hermann and Sabrina Mervin, eds., Shi’i Trends and Dynamics in Modern Times (XVIIIth-XXth centuries) Beirut, Orient-Institut Beirut.

Mufīd (Shaykh al-) (1993). Masār al-Shīa fì Mukhtașar al-Tawārikh al-Sharīa. Tehran: Dār al-Mufĩd.

Muhaddithī, Jawād (2009). Farhang-e 'Āshūrā (dictionnaire de 'Āshūrā). Qom: Nashr-e Ma'rūf.

Neuve-Eglise, Amélie (2021, forthcoming). Modalités de l'extension d'une temporalité sacrée: la marche d'Arbaīn en Iran contemporain, entre logiques spirituelles et sociopolitiques. Archives des sciences sociales des religions.

Parsapajouh, Sepideh (2016). La chāsse de l'imam Ḥusayn. Fabrique et parcours politique d'un objet religieux de Qom à Karbala. Archives des sciences sociales des religions. La force des objets. Matières à expériences 174, pp. 49-74.

Parsapajouh, Sepideh (2021, forthcoming). Un cosmopolitisme religieux. La ville de Qom au miroir des circulations transnationalesin: Thierry Boissière and Yoann Morvan (ed.), Un Moyen-Orient ordinaire. Entre mobilités et consommation (Alep, Istanbul, Koweit, Qom, Téhéran), Editions Diacritiques.

Parsapajouh, Sepideh (2019a). Sous le regard des martyrs à Téhéran. Une approche anthropologique de la production de l'iconographie urbaine. L'Homme. Revue française d'anthropologie 229, pp. 7-48.

Parsapajouh, Sepideh (2019b). A qui sont ces martyrs? Discussions autour des tombes des martyrs au cimetière de Behesht Zahra de Téhéran. Remmm. Revue des mondes musulmans et de la Méditerranée. Chiismes politiques 145, pp. 29-58.

Pishwāi, Mahdi, ed. (2016). Tārikh qiyām va maqtal jāmi 'Sayyid al-Shuhadā. Volume 2. Qom: Intishārāt-e Emām Khumaynī.

Richard, Yann (1996). Qom, un lieu sacré en Iran. In: M.A. Amir-Moezzi, ed., Lieux d'islam. Paris: Autrement, pp. 6o-9.

Ṣadūq (Shaykh) (1999). 'Uyūn akhbār al-Riżā. Volume 2. Tehran: Enteshārāt-e Jahān.

Șadūq (Shaykh) (1979). Al-Amāli. Beirut: A'lamī.

Ṣadūq (Shaykh) (1992). Man lā yaḩ̇̇uruhu al-faqīh, ed.'Alī Akbar Ghaffārī. Volume 4. Qom: Enteshārāt-e Eslāmi.

Tābandeh, Sulțān Ḥusayn (1960). Safar-nameh Afghānistān va Pākistān. Kholāseh. Revue Majmū'a Hekmat (summarized by Muhammad Dibāj), N 51 , pp. 32-34, (1339 h.s.).

Tabarī, Muhammad b. Jarīr (1992). Dalāil al-imāma. Qom: Mu’assisat al-Bi'tha (1413 h.l.). 
Tabbaa, Yasser and Mervin, Sabrina (2014). Najaf: The Gate of Wisdom. History, Heritage and Significance of the Holy City of the Shi'a. (Photographs by Erick Bonnier). Paris: Unesco Publishing.

Terrier, Mathieu (2017). Le combat sacré des vaincus de l'histoire: experience et presentations du jihad dans le chiisme Imamate ancient. Journal Asiatique 305 (1), pp. 23-31.

Ṭūsī (Shaykh), Muḥammad b. Ḥasan (1993). Al-Amālì. Qom: Dār al-Thaqāfa.

\section{Notes}

See i.e.:Denise Aigle (2000).Miracle et karāma, hagiographiesmédiévales compares. Paris: E PHE;Sossie Andezian (2001). Expériences du divin dans l'Algérie contemporaine. Adeptes des saints de la région de Tlemcen. Paris: CNRS Editions; Nelly Amri, and Denis Gril, eds. (2019).Saintet sainteté dans le christianisme et l'islam. Le regard des sciences de l'homme. Maisonneuve \& Larose; Nelly Amry (2019). Croire au Maghreb médiéval. La sainteté en question. Paris: Cerf; Katia Boissevain (2006). Sainte parmi les saints. Sayyda Mannübiyya ou les recompositions cultuelles dans la Tunisie contemporaine. Paris:Maisonneuve et Larose; Michel Boivin (2019), The Hindu Sufis of South Asia. Partition, Shrine Culture and the Sindhis of India. London: I.B. Tauris; Henri Chambert-Loire and Claude Gillot eds. (1995). Le culte des saints dans le monde musulman. Paris: Ecole française d'Extrême Orient; Catherine Mayer-Jaouen (2004). Histoire d'un pèlerinage légendaire en Islam. Paris: Aubier; M. Chodkiewicz (1995). La sainteté et les saints en Islam. In: Henri Chambert-Loire and Claude Gillot, eds., Le culte des saints dans le monde musulman. Ecole française d'Extrême Orient, pp. 13-23; S. Chiffoleau and A. Madoeuf (2005). Cf. Catherine Mayeur-Jaouen (2010).

3 I emphasize this idea of "encounter", but I must point out that the importance of the "journey", and "peregrination," is not absent from Shi'ism, both as a physical trial and a spiritual path, cf. Amélie Neuve-Eglie (to be published 2021); Géraldine Chatelard and Sabrina Mervin (2019).

4 On the subject of the spiritual state, and devotional and ritual practices (ādāb of the pious visit), I am currently preparing another article, complementary to this article: "La zīyāra de l'imam Ḥusayn dans le chiisme duodécimain. Pouvoir du lieu, médiation du texte", to be published in 2021.

5 Here I do not touch upon the theme of practices and how believers visit their saints, which is the subject of another article cf. note 4 .

6 Kulaynī, Ușūl al-Kāfí, vol. 2, p. 14 and vol. 4, p. 175; Mohammad Ali Amir-Moezzi also quotes this hadith, 2007, p. 215.

7 See Amir-Moezzi's precious monograph on the walāya, 2002.

8 Shaykh Ṣadūq, 'Uyūn a khbār al-Riżā, vol. 2, 27; Shaykh Ṭūsī, al-Amālī, p. 633.

9 for an in-depth analysis of the concept waläya in the Tewlever shiisme, see Amir-Moezzi, 2002; and 2007 and 2018, Index, s.v. "walāya."

10 I am currently preparing another article entitled "The Imam's Husayn Ziyāra in Twelver Shiism. Power of Place, Mediation of the Text (Ziyārat al-Wārith)" where I speak more in detail on this subject.

11 See Amir-Moezzi, 2007.

12 There is no certainty about her date of birth; this date (two years after the first revelation) is mentioned by Shaykh Mufīd, Mazār al-Shī a, p. 54 and al-Kaf'amī, al-Misbāh, p. 512. $\bar{a} l-T a \bar{h} \bar{a}$ is an expression used to refer to the family of the Prophet. On this subject, see Sepideh Parsapajouh, 2016 and 2020. In a famous hadith of the Prophet, see Sadūq, 1979: 57. Cf. e.g. Ṭabarī, Dalāil al-imāma, 1413, p. 21. "Indeed Allah desires to repel all impurity (Rijs) from only you, Ahl al-Bayt (People of the Household), and purify you with a thorough purification" (Q. 33:33).

18 In addition to the seventh Imam, two other historical Shici personalities bear this title, namely 'Abbās, the half-brother of Imam Ḥusayn (of 'Alī and Umm al-Banīn) and 'Alī Asghar, new-born son of Ḥusayn and Rubāb, both of whom were killed in Karbala (cf. Jawād Muhadithi, 20o9, p. 316).

19 It is also worth mentioning that this shrine, like some others, has been subjected to destruction and reconstruction throughout history, most recently in 2005 and 2007 (by the Iraqi branch of Al-Qaeda under the guidance of Abū Musā al-Zarqawi) and also in 2014 (by the forces of Islamic State of Iraq and the Levant). Reconstruction, financed by the notorious Iraqi Shi'i authority Sayed Ali Sistani, and managed by the Iranians, started in 2010 and was finally implemented in 2017. cf. Amir-Moezzi, 2007, p. 254 and 272.

21 About the representation of the Mahdi and his role at the end of time, see Mathieu, Terrier, 2017.

About these texts, see Amir-Moezzi, 2021. 
23 Selon les chiffres de l'Organisation des lieux saints du pays. https://www.radiofarda.com/a/24289646 .html.

24 See Yann Richard, 2010; Parsapajouh, 2021.

25 See Albera \& Penicaut, 2015.

26 A very pious man, ascetic and pure, according to the Shi'i hadith, who would have been in contact with Imam 'Alī and his two sons. According to people's beliefs and also to the historical narration, he lived in Kufa and could have been spared during the Karbala massacre, but he joined Imam Husayn and stayed by his side until the end, which is why he is very venerated.

27 He is particularly respected by the Shi'a because of his life story: he was a Kufa commander in Yazid's army, but, in front of Imam Husayn's army, he changed sides and joined the Imam's party until he sacrificed himself as a martyr at his side.

28 One of Imam 'Alì's close companions, and elderly man who was killed because of his loyalty to Imam Husayn, just before the battle of Karbala. According to the sacred narratives, Imam Husayn is said to have mourned his death when he received the news on his way to Kufa.

29 About this revolt, see Torsten Hylén, 2018.

30 About the Iranian martyrs, see Parsapajouh, 2019a and $2019 \mathrm{~b}$.

31 See: Shaykh Ṭūsī, 1993: $5^{21}$ and Ibn Bābūya (Shaykh Saduq), 1992: pp. 398-9.

32 Hafiz Nūr Muhammad's manuscript (1946) is based on older sources, from more or less ancient scholars of the Balkh and Harāt regions. Given the way the author relates to the history, he seems to be both Shici and Sunni, respecting even the first three caliphs, the Umayyad Mu'āwiyya, but also all the Imams of the Shi'a, out of compassion with the suffering caused by the Umayyads.

33 Hafiz Nūr Muḥammad's Manuscript, 1946/1325: 5.

34 Ibid., pp. 19-46.

35 I cite the hadith quoted by Hafiz Nūr Muhammad's, but don't know anything about its authenticity (cf. next note).

36 This account is indicated also in the travelogue of Sufi Master Sulțān Husayn Tābandeh (or Rezā 'Alī Shah, a Sufi master), who travelled through Afghanistan in the 196os, and collected popular narratives about this place (Sulțān Husayn Tābandeh, 196o/1339). His account has never been published, but a summary of it was published in Hekmat magazine in Qom. One of the sources is: Tārikh-e Mazār-e Sharīf, Hafiz Nūr Muhammad Kahgedâ'î, 1946 (1325): pp. 20-46. I couldn't find the text of Rezā 'Alī Shāh, but I had access to other rare texts that referred to him, such as: http:// afghanistansafar.blogfa.com/post/13;http://www.bsharat.com/id/1/3/4.html; https://anthropology. ir/article/21812.html; (consulted 04.05.2020). Thus, what follows here is taken from the manuscript of Hafiz Nūr Muhammad's manuscript, which I consulted, as well as the summaries of the text of Rezā 'Alī Shah quoted by others researchers (both being in conformity).

37 Hafiz Nūr Muhammad Kahgedâ'î, Ms., 1945: pp. 26-7.

38 cf. also 'Alī b. Abī Bakr Harawī, 1214, a geographical book that contains a lot of information about various holy places.

39 Muhammad Zakī Ibrāhim, 2003 (1424), pp. 68-9.

40 Rasūl Ja'farīyān, 2000 (1389), vol. 8, 271.

41 Sayyid Muhsin al-Amīn, Áyān al-Shi'a, 1982 (1403), vol. 7, pp. 140-1.

42 Yāqut Humawī, vol. 5, p. 166, in: Mahdi Pishwāi, 2016 (1395), vol. 2, p. 585.

43 About this shrine see S. Parsapajouh, 2016.

44 About this city, see Yasser Tabbaa and Sabrina Mervin, 2014; S. Mervin 2010.

45 About this city, see S. Parsapajouh, 2021.

46 Majlisi, Bihār, vol. 11, p. 149.

47 Kulaynī, Ușūl al-Kāfì, vol. 3, p. 243.

48 Sister of the eighth Imam, who on his way from Baghdad to Marv where she was to join her brother, stopped at Qom, among the adepts of "the holy family of the Prophet" (Ahl al-Bayt) and in 200/816 died there after seventeen days of suffering in the house of a notable member of the Shici family, Mūsā b. Khazraj Ash'arī. She was buried in the same house, in an orchard on the outskirts of the city. This is not a recent phenomenon. Thus, Bémont writes "According to the Count de Sercy, who visited it at the end of the first third of the nineteenth century, the holiness of the city was so renowned that corpses were transported from Central Asia to be buried there" (1969: 179).

$50 \quad$ Ibn Bābūya, 1992, Man lā Yaḩ̇̇uruhu al-Faqīh, vol. 1, p. 15०; p. 120.

51 This mosque is huge today (cf. Parsapajouh, 2021.), but for a long time it was a small and modest legendary place cf. Amir-Moezzi, 1996.

$5^{2}$ About the footprints, see Michel Boivin's article in this issue.

53 About the substitutes, see Hiba Abid's article in this issue.

54 Amir-Moezzi, 2008.

55 Cf. S. Parsapajouh, 2016. 